African J. Biol. Sci., 14 (2): 103-125 (2018)

ISSN 1687-4870

www. ajbs.journals.ekb.eg

e- ISSN 2314-5501 (online)

E.mail: aasdjournal@yahoo.com

\title{
Physicochemical studies on starch isolated from Egyptian wheat cultivars
}

\author{
Marwa M. A. Mahrous ${ }^{1, *}$, Nasser S.A.M.Khalil ${ }^{1, *}$, Mohamed A.Mekewi ${ }^{2}$ and Amr \\ A.Elsayed $^{3}$ \\ 1- Regional Center for Food and Feed, Agricultural Research Center, Giza, EGYPT \\ 2- Chemistry department, faculty of science, Ain shams university, Cairo, Egypt. \\ 3-National Research center, Cellulose unit, Dokki, Giza, Egypt. \\ *Corresponding author; nasserkhalil_23@hotmail.com
}

\begin{abstract}
In the current study, starch was isolated from two Egyptian wheat cultivars, namely, Wheat Durum BeniSuef 1 and Bread Wheat Misr 1. The isolated starches were subjected to versatile physicochemical study, comprising, proximate analyses (contents of ash, moisture, protein, total carbohydrates), total organic matter (TOM), total organic carbon (TOC), undesired elemental content (chromium, nickel, arsenic, lead and cadmium), nutritive elemental content (sodium, potassium, phosphorus, magnesium, calcium, manganese, iron, cobalt, copper, zinc and selenium), other elements (molybdenum, tin and antimony), amylose, amylopectin, $\mathrm{pH}$ value, water binding capacity (WBC), total hydrolysable carbohydrates, swelling power and solubility. Spectral studies including Fourier transform infrared (FT-IR) and X-Ray diffraction pattern of the isolated starches were thoroughly envisaged.
\end{abstract}

Key words: Physicochemical properties, Starch, isolation, wheat, cultivars, FT-IR, X-ray

\section{INTRODUCTION}

Since prehistoric times and throughout the recorded history till recent era wheat is one of the oldest, most extensively cultivated, and higher nutritional value crop in the world, on which different industries were based (Olsen, 1994; Yoo and Jay, 2002). Starch is the most abundant constituent of wheat grains (ca. 70-75\%) that includes two types of $\alpha$-D-glucose polymers: amylose and amylopectin. Amylose which is a linear molecule, consists of $\alpha$ - $(1,4)$-linked D-glucopyranosyl units having a degree of polymerization (DP) in the range of 500-6000 glucose residues. Amylose molecule has very few $\alpha$ $(1,6)$ - linkages, whereas amylopectin molecule has a highly branched structure linked with $\alpha$-(1,6)-glucosidic bonds. Amylopectin has greater DP ranging from 3 $\times 10^{5}$ to $3 \times 10^{6}$ glucose units (Hung et al.,
2006; Tester et al., ,2004). Depending on the botanical source, amylose/amylopectin ratio in starches varies; normal wheat starches consist of 22-35\% amylose and $65-78 \%$ amylopectin, but the waxy (amylose-free) wheat starches contain essentially $100 \%$ amylopectin (Cai and Shi, 2010).

Because of many factors, like being cheap natural material and the ease with which its physicochemical properties can be altered [through chemical or enzymatic modification and/or physical treatment (Jobling, 2004)], starch has been a useful material for different wide and versatile applications, like, processed food, paper, textile, chemical and pharmaceutical industries.

Starch is a major component of food products because, its pasting properties, retrogradation, and viscosity characteristics are extremely important to the appearance, 
Marwa M. A. Mahrous et al.

structure, and quality of foods. In addition, wheat grain starch is an important component of the fermentation process and directly affects the quality of the dough (Goesaert et al., 2005; Yasui et al., 2009). This is due to the fact that different amylose/amylopectin ratios and structure of starch granules affect the physicochemical properties, the processing properties of flour, and the edible quality of the end-use products (Kozlov et al., 2006; Kozlov et al., 2007).

Proper rate of glucose release and absorption from digesting starch may play an important role in human health by maintaining proper blood glucose levels (Zhang et al., 2008). According to the rate and extent of an in vitro digestion, starch has been classified into rapidly digestible starch (RDS), slowly digestible starch (SDS) and resistant starch (RS) (Englyst and Hudson, 1996). SDS is the starch fraction that is digested completely in the small intestine at a lower rate than RDS, SDS tends to provide a sustained supply of glucose with a low glycemic index (GI) that may contribute to the control and prevention of various hyperglycaemia-related diseases (Cummings et al., 1996). Besides, SDS may be beneficial to maintaining body weight when it is used as a raw material in the production of foodstuffs (Jenkins et al., 2002). Hence, foods containing higher amount of SDS are regarded as functional foods with low GI (Han et al., 2006; Zhang and Hamaker, 2009), and SDS has attracted more attention in recent years.

Till the moment, there is no single reported publication studying the physicochemical properties of starches isolated from different Egyptian crop cultivars. This fact, together with previously mentioned facts prompted us to isolate starches from two Egyptian cultivars, namely, Wheat Durum BeniSuef 1 and
Bread Wheat Misr 1 for studying their various physicochemical properties.

\section{MATERIALS AND METHODS Materials:}

Two cultivars of wheat, namely Wheat Durum BeniSuef 1 and Bread Wheat Misr 1, and other cultivar of corn namely Giza TWC 352 Y 352, were obtained from Field Crops Research Institute (FCRI), Agriculture Research Center, Giza, Egypt. The obtained cultivars were stored in refrigerator at $0-5^{\circ} \mathrm{C}$ till the time of analysis.

\section{Chemicals and reagents}

All chemicals were purchased from Sigma, Aldrich, Merck, Fluka, Riedel-de Haën, Fisher and were of analytical grade. All chemicals and reagents used for elemental analysis were of Trace SELECT metal grade.

\section{Starch isolation}

Wheat grains were washed with tab water, and soaked in $0.16 \% \quad \mathrm{Na}_{2} \mathrm{~S}_{2} \mathrm{O}_{5}$ solution at $50^{\circ} \mathrm{C}$ in oven for $24 \mathrm{~h}$. The supernatant was discarded; wheat grains and corn kernels were washed two times, mixed with $\mathrm{Na}_{2} \mathrm{~S}_{2} \mathrm{O}_{5}$, blended with a blender and then passed through a $75 \mu \mathrm{m}$ sieve. The sediment on the sieve was taken, blended with $\mathrm{Na}_{2} \mathrm{~S}_{2} \mathrm{O}_{5}$ and passed through the sieve again. The starch paste was re-suspended in $0.1 \% \mathrm{NaOH}$ solution and left soaked in fridge for $48 \mathrm{~h}$. The suspension was then centrifuged at $3431 \mathrm{rpm}$ for $20 \mathrm{~min}$, washed successively with $0.1 \% \mathrm{HCl}$ followed by deionized water (each wash includes centrifugation and discarding supernatant) then methanol was added and the suspension was left soaked in methanol overnight. After discarding methanol, acetone was added twice and the mixture was separately centrifuged two successive times $3431 \mathrm{rpm}$ for $20 \mathrm{~min}$ (including discarding the supernatant in each time). The formed starch 


\section{Physicochemical studies on starch isolated from Egyptian wheat cultivars}

was collected by filtration on Whatman 1 filter paper ( $24 \mathrm{~cm}$ diameter), washed with petroleum ether and then completely dried in an oven at $40^{\circ} \mathrm{C}$ for $24 \mathrm{~h}$ in an air oven.

\section{Poximate analysis}

\section{Ash content}

Determination of ash content was made as described by AOAC (2012). An empty clean crucible for each sample was placed in a muffle furnace at $600^{\circ} \mathrm{C}$ for an hour, cooled in desiccator and then weighed $\left(\mathrm{W}_{1}\right)$. About one gram of each starch sample $\left(\mathrm{W}_{2}\right)$ was put in crucible. The sample was ashed in muffle furnace at $550{ }^{\circ} \mathrm{C}$ for at least 6-8 h. The appearances of gray white ash indicate complete oxidation of all organic matter in the sample. After ashing furnace was switch off. The crucible was cooled in a desiccator and weighed $\left(\mathrm{W}_{3}\right)$. Percent ash was calculated by following formula:

$\%$ Ash $=$ (Difference in weight of ash $\left./ \mathrm{W}_{2}\right) \times 100$. Difference in weight of ash= $\mathrm{W}_{3}-\mathrm{W}_{1}$.

\section{Fat content}

Fat content was measured using filter bag technique by extracting with petroleum ether (bp 40-60 ${ }^{\circ} \mathrm{C}$ ) using ANKOM-XT 15 Extractor (AOCS Official Method).

\section{Moisture content}

Moisture was determined as described by (AOAC, 2012) via oven drying method. About $1.5 \mathrm{~g}$ of each starch sample was accurately weighed in clean, dried crucible/or glass beaker $\left(\mathrm{W}_{1}\right)$. The crucible was allowed to dry overnight in an oven at $100-105^{\circ} \mathrm{C}$ until a constant weight was obtained. Then the crucible/ or glass beaker was placed in a desiccator for $30 \mathrm{~min}$ to cool. After that it was weighed again $\left(\mathrm{W}_{2}\right)$. The percent moisture was calculated by following formula: \%Moisture $=100 \times\left(\mathrm{W}_{1^{-}}\right.$ $\left.\mathrm{W}_{2}\right)$ /sample weight, where, $\mathrm{W}_{1}=$ Initial weight of crucible + Sample, $\mathrm{W}_{2}=$ Final weight of crucible + Sample.

\section{Protein Content}

Protein content was quantified as described by (AOAC, 2012) using Kjeltec ${ }^{\mathrm{TM}}$ 8400 analyzer unit (FOSS). A specific weight or of dried samples was taken in a kjeldahl digestion flask. The sample was digested with hot concentrated sulfuric acid containing $\mathrm{CuSO}_{4} .5 \mathrm{H}_{2} \mathrm{O} / \mathrm{K}_{2} \mathrm{SO}_{4}$ catalyst mixture. After complete digestion (color of digested material turns to blue green in color), the digest was cooled, diluted with water and subjected to distillation step. Distillation was continued for few minutes and $\mathrm{NH}_{3}$ produced was collected as $\mathrm{NH}_{4} \mathrm{OH}$ in a receiver containing certain volume of $4 \%$ boric acid solution with few drops of modified methyl red indicator. The distillate was then titrated against standard $0.1 \mathrm{~N} \mathrm{HCl}$ solution till the appearance of pink color. A blank was also run through all steps as above. Percent crude protein content of the sample was calculated by using the following formula: $\%$ Crude Protein $=6.25$ $\mathrm{x} \% \mathrm{~N}$.

\section{Total carbohydrate content}

Total carbohydrate is either measured specrophometrically using phenol sulfuric acid method reported by (Dubois et al., 1956) or calculated by difference method (AOAC, 2012).

\section{Total organic matter content and total organic carbon}

About $10 \mathrm{gm}$ of the starch was weighed dried in oven at $105^{\circ} \mathrm{C}$ for overnight, in a pre weighed crucible. After drying the crucible and cooling in a desiccator to room temperature for $1 / 2 h$, the crucible with its contents was recorded $\left(\mathrm{W}_{1}\right)$. Thereafter, the crucible with its contents was ignited in a Muffle furnace at $650-700^{\circ} \mathrm{C}$ for $6-8 \mathrm{hrs}$. After cooling to 
Marwa M. A. Mahrous et al.

room temperature in a desiccator for $1 / 2 \mathrm{hr}$, the crucible with its contents was weighed $\left(\mathrm{W}_{2}\right)$.

Total Organic matter\%= $100 \times$ [Weight after drying (W1) - Weight after ashing]/ sample weight.

Total $\mathrm{C} \%=($ Total organic matter $) / 1.724$ (AOAC, 2012; FCO, 1985).

Note; the reference time of AOAC(2012) and FCO (1985) is at least $6 \mathrm{~h}$ for drying at $105^{\circ}$, but the actual time for drying starch samples in the current work was overnight, to secure complete drying and constant weight.

\section{Elemental content of starches}

Elemental analysis was done based on dry matter. Thus, starch samples (about 5 gm) were dried in an air oven at $100^{\circ} \mathrm{C}$ overnight prior to analysis. Starch samples were digested using microwave digestion technique (speed wave micro wave digestor, Berghof). About 0.2-0.5g of each kind of starch was weighed in the appropriate microwave vessel using trace metal grade concentrated nitric acid (Fisher, 67-69\%). After digestion, all samples were diluted to $100 \mathrm{ml}$ with deionized water. Starches were analyzed using either Graphite Technique (via ContrAA 700 atomic absorption spectrometer, Analytikjena) or inductively coupled plasma technique [via Optima 2000 DV ICP, PerkinElmer instruments), where contents of arsenic (As), cadmium (Cd), chromium $(\mathrm{Cr})$, lead $(\mathrm{Pb})$, nickel $(\mathrm{Ni})$, selenium (Se), tin (Sn), cobalt (Co), antimony ( $\mathrm{Sb}$ ), molybdenum (Mo), copper $(\mathrm{Cu})$, manganese $(\mathrm{Mn})$ were quantified using graphite technique (ContrAA 700 appliaction notes) contents of calcium (Ca), iron $(\mathrm{Fe})$, zinc $(\mathrm{Zn})$, potassium $(\mathrm{K})$, sodium $(\mathrm{Na})$, phosphorus $(\mathrm{P})$ and magnesium $(\mathrm{Mg})$ were quantified using ICP technique (AOAC, 2012).

\section{Amylose content and amylopectin}

Estimation of amylose was achieved as reported by Sowbhagya and Bhattacharya (1971). Each starch sample was defatted using petroleum ether (bp $40-60{ }^{\circ} \mathrm{C}$ ) using using ANKOM-XT 15 Extractor. In a $50 \mathrm{~mL}$ conical flask, about $100 \mathrm{mg}$ (on dry matter basis) of defatted starch sample and to it was added $1 \mathrm{~mL}$ of ethyl alcohol, followed by 10 $\mathrm{mL}$ of $1 \mathrm{~N}$ sodium hydroxide and the mixture was kept overnight at room temperature. The next day, sample was boiled in a water bath at $100{ }^{\circ} \mathrm{C}$ for $15 \mathrm{~min}$, cooled and then transferred quantitatively to $100 \mathrm{~mL}$ conical flask and finally made up to volume with deionized water. An aliquot v (2.5-5 mL) of the dispersion was accurately pipetted out into a $100 \mathrm{~mL}$ conical flask followed by successive addition of $50 \mathrm{~mL}$ of water and $1 \mathrm{~mL}$ of $1 \mathrm{~N}$ acetic acid. After shaking the whole mixture, $2 \mathrm{~mL}$ of $0.2 \%$ iodine in $2 \%$ potassium iodide solution was added and the volume was made up to mark with deionized water, and kept at $30{ }^{\circ} \mathrm{C}$ for $20 \mathrm{~min}$. Absorbance was read at $620 \mathrm{~nm}$ in a UV-visible spectrophotometer (model Specord-200 analytikjena) with a blank (without sample). Standard amylose (Sigma, Germany), was prepared by dissolving in a $100 \mathrm{~mL}$ conical flask $100 \mathrm{mg}$ amylose powder in $1 \mathrm{~mL}$ ethyl alcohol and $10 \mathrm{~mL} 1 \mathrm{~N}$ sodium hydroxide, covered and heated in a water bath at $100{ }^{\circ} \mathrm{C}$ for $2 \mathrm{~min}$. The solution was cooled at room temperature and $1 \mathrm{~mL}$ was accurately pipetted to which $50 \mathrm{~mL}$ double deionized water, $1 \mathrm{~mL}$ of $1 \mathrm{~N}$ acetic acid and $2 \mathrm{~mL}$ of $0.2 \%$ iodine in $2 \%$ potassium iodide solution were added, made up to volume with deionized water, and kept at $30{ }^{\circ} \mathrm{C}$ for $20 \mathrm{~min}$. The color was also read at $620 \mathrm{~nm}$.

The total amylose composition was calculated using the formula of Sowbhagya and Bhattacharya (1971): Amylose content $(\%$ dry basis $)=(\mathrm{R} \times$ a x 1 x 100 $) /(\mathrm{A} \times \mathrm{r} \times \mathrm{v})$ where: 


\section{Physicochemical studies on starch isolated from Egyptian wheat cultivars}

$\mathrm{R}=$ absorbance of sample, $\mathrm{A}=$ absorbance of standard amylose, $\mathrm{a}=$ weight of standard amylose $(\mathrm{mg})$ in $100 \mathrm{~mL}, \mathrm{r}=$ =weight of sample taken $(\mathrm{mg})$ in $100 \mathrm{~mL}$ and $\mathrm{v}$ is the aliquot volume (mentioned above, $2.5-5 \mathrm{~mL}$, taken from the $50 \mathrm{~mL}$ solution and diluted to $100 \mathrm{~mL}$ solution).

Amylopectin was calculated by difference of total carbohydrate content and amylose content.

\section{8. pH Value of the isolated starches:}

It was measured in starch slurries of $25 \mathrm{~g}$ starch in $50 \mathrm{ml}$ distilled water as described by AOAC (2012) and FCO, (1985). $\mathrm{pH}$ value was measured by ORION 5 STAR multifunction ( $\mathrm{pH}$. ISE. COND. DO) benchtop meter (Thermo Electron Corporation)

\section{Water binding capacity measurement}

WBC of all starches was determined using method described by Yamazaki (1953) and Medcalf and Gilles (1965). with some modifications. A suspension of $2.5 \mathrm{~g}$ from each starch (dry weight) in $37.5 \mathrm{ml}$ deionized water was agitated for $1 \mathrm{~h}$ on a shaker and centrifuged at $5430 \mathrm{rpm}$ for 10 min (equivalent to $3000 \mathrm{~g}$ using Sigma centrifuge). The supernatant (free water) was removed from the wet starch, which was drained for $10 \mathrm{~min}$, and the wet starch was weighed.

\section{Total hydrolysable carbohydrates}

Sampleswere measured as previously reported by Dubois et al.(1956). Each sample was prepared by dispersing about $100 \mathrm{mg}$ (dry based matter) of each starch sample in $1 \mathrm{~mL}$ of ethyl alcohol in a $100 \mathrm{~mL}$ conical flask (previously washed successively with concentrated boiled nitric acid then deionized water, followed by drying at $100^{\circ} \mathrm{C}$ overnight), slowly stirred, treated with $9 \mathrm{~mL}$ of $1 \mathrm{~N}$ sodium hydroxide, and heated in boiling water bath for $10 \mathrm{~min}$ with continuous shaking. The sample was cooled to room temperature and transferred quantitatively to a $100 \mathrm{~mL}$ volumetric flask, and made up to volume with deionized water. Accurately pipetted $5 \mathrm{~mL}$ of this solution was neutralized using $0.1 \mathrm{~N} \mathrm{HCl}$ and phenolphthalein indicator. To an aliquot volume of the sample was added, $1 \mathrm{~mL}$ of $5 \%$ phenol followed by $5 \mathrm{~mL}$ concentrated $\mathrm{H}_{2} \mathrm{SO}_{4}$ cautiously on the side of the test tube. After cooling the test tubes to room temperature for $30 \mathrm{~min}$ and the absorbance was read at $490 \mathrm{~nm}$ using a UVspectrophotometer (mode Specord-200 analytikjena) (with a blank (without sample). Standard glucose was treated the same way as the samples. Through the software of the instrument, linear regression model was applied to develop the prediction equation that was used for determining the glucose concentration of the samples.

\section{Swelling Power and Solubility}

Were determined as previously reported by Schoch (1964) and Unnikrishnan and Bhattacharya (1981) with some modifications as follow: A suspension of about $1 \mathrm{~g}$ of each isolated starch (dry weight) in about $40 \mathrm{~mL}$ deionized water was incubated in water bath at each of the investigated temperature, separately $\left(30{ }^{\circ} \mathrm{C} /\right.$ $60{ }^{\circ} \mathrm{C} / 95^{\circ} \mathrm{C}$ ) for $30 \mathrm{~min}$. They were then centrifuged at $8300 \mathrm{rpm}$ for $20 \mathrm{~min}$. Supernatant was decanted carefully and kept for measuring solubility, and the residue was weighed for swelling power determination. An aliquot volume of the supernatant was pipetted out to an empty preweighed clean and dry beaker that was kept overnight in an air oven. After complete evaporation of the contents of the beaker, it was dried in an air oven at $100-105^{\circ} \mathrm{C}$ overnight.

Swelling power $=(\mathrm{Wt}$ of the wet residue Wt of the dried sample)/Wt of sample on dry base 
Marwa M. A. Mahrous et al.

Solubility $=[(\mathrm{Wt}$ of the dry residue from $)$ (100/Aliqot volume)(100)]/Starch weight.

\section{Fourier transform infrared (FT-IR) spectroscopy}

The change in chemical structure of the starch was qualitatively analyzed by using FT-IR (Spectrum Two, PerkinElmer FTIR spectrometer). Samples were prepared by grinding the finely powdered starch with $\mathrm{KBr}$. The spectrum was recorded over the wave number range between 400 and 4000 $\mathrm{cm}^{-1}$. The starch samples were dried at $105^{\circ} \mathrm{C} \quad \mathrm{h}$ before analysis to avoid interference by moisture and kept in a desiccator to be cooled to room temperature before its scanning.

\section{X-Ray diffraction pattern}

The X-ray patterns of the dry isolated starches were done at the Nano and Advanced Material Central Lab (NAMCL), Agriculture Research Center, Giza, Egypt using an X-ray diffractometer ( $X^{\prime}$ Pert Pro PANanalytical, Netherland) operated at 30 $\mathrm{mA}$ and $40 \mathrm{kV}$. The scanning region of the diffraction angle (2e) was from 40 to 80 with scan step time 0.5 second. Anode material is copper with $\mathrm{k}-\alpha 1=1.54060$ and $\mathrm{k}-\alpha 2=1.54443$.

\section{RESULTS AND DISCUSSION}

\section{Physicochemical properties of isolated} starches

\subsection{Proximate analysis of isolated starches}

Table (1) briefs the proximate analysis of isolated starches from the studied wheat cultivars Durum BeniSuef1 and wheat Bread Wheat Misr1. It is clear from Table (1) that cultivar variation affects the chemical composition of the isolated starches. Thus, cultivar Durum BeniSuef 1 recorded higher ash $(0.026 \%)$ and protein (3.72\%) contents when compared to cultivar Bread Wheat Misr 1 which recorded $0.01 \%$ and $0.55 \%$, respectively. On the other hand, cultivar Bread Wheat Misr 1 recorded higher fat $(0.79 \%)$, moisture $(9.96 \%)$ and total carbohydrate $(88.96 \%)$ than cultivar Durum BeniSuef 1 that recorded $0.64 \%, 8.86 \%$ and $86.75 \%$, respectively.

Table (1). Composition (\%) of isolated starches from wheat cultivars

\begin{tabular}{llllll}
\hline \multicolumn{1}{c}{ Wheat cultivar } & \multicolumn{1}{c}{ Ash } & Fat & Moisture & Protein & $\begin{array}{c}\text { Total } \\
\text { Carbohydrate }\end{array}$ \\
\hline Durum BeniSuef 1 & 0.026 & 0.64 & 8.86 & 3.72 & 86.75 \\
Bread Wheat Misr 1 & 0.01 & 0.79 & 9.69 & 0.55 & 88.96 \\
\hline
\end{tabular}

The variation in chemical composition was noted by Kuar et al. (2007) who reported ash content in the range of 0.06 to $0.45 \%$ for different potato cultivars grown at different locations.

\subsection{Total organic matter of isolated starches}

Table (2) shows the total organic matter content (TOM) as well total organic carbon content of the isolated starches. From table 2 it is clear that cultivar Durum BeniSuef 1 recorded higher total organic matter $(91.12 \%)$ as well as total organic carbon content (52.85\%) when compared to cultivar Bread Wheat Misr 1which recorded $90.30 \%$ and $52.38 \%$, respectively. These results support those obtained in table 1 , as it is well known that the major organic matter in starch include fat, protein and carbohydrate. 
Table (2). Total organic matter (TOM) and total organic carbon (TOC) contents of isolated starches (\%)

Wheat cultivar

$$
\text { Total Organic matter (TOM) Total organic carbon (TOC) }
$$

\begin{tabular}{lll}
\hline Durum BeniSuef 1 & 91.12 & 52.85 \\
Bread Wheat Misr 1 & 90.30 & 52.38 \\
\hline
\end{tabular}

\subsection{Concentration ofundesired elements in isolated starches}

Table (3) illustrates the concentration of some undesired elements in starch as they are reported to be undesirable in animal feed (DIRECTIVE 2002/32/EC). Chromium $(\mathrm{Cr})$, nickel $(\mathrm{Ni})$, arsenic (As), lead $(\mathrm{Pb})$ and cadmium $(\mathrm{Cd})$ were measured using the graphite technique in $\mathrm{ppb}$ concentration unit $(1 \mathrm{ppb}=0.001 \mathrm{ppm})$. Arsenicsignal (at $\lambda=$ $193 \mathrm{~nm})$, when measured using the high resolution continuum source (HR-CS) is sometimes interfered with PO molecular signal, coming from reaction of phosphorus in the sample and nitric acid. Thus, in Table 3 , the concentration of arsenic was measured using two different techniques, the first is the direct measurement technique, while the second techniques measurement after applying the recommended PO correction model ( $\mathrm{As}^{\mathrm{a}}, \mathrm{As}^{\mathrm{a}, \mathrm{b}}$ in Table 3 ). The difference between the two measurements assured the existence of PO molecular interfering signal at the same wave length of arsenic. So, the accurate results were obtained after compensation of the direct overlap of element and PO molecular absorption lines and performing the spectrum correction as reported (ContrAA300/600/700).As in arsenic measurement, cadmium can suffer PO molecular signal overlap with cadmium at measuring line $\lambda 228 \mathrm{~nm}$. Thus both measurements with and without PO correction model are shown in Table 3. There is no much great difference between the two measurements $\mathrm{Cd}^{\mathrm{a}}, \mathrm{Cd}^{\mathrm{a}, \mathrm{b}}$.

The presented data in Table (3) reveals that starch isolated from cultivar Durum BeniSuef 1 recorded higher contents of chromium $(\mathrm{Cr} ; 1196 \mathrm{ppb})$, arsenic $\left(\mathrm{As}^{\mathrm{a}}\right.$; $\left.998.3 \mathrm{ppb} / \mathrm{As}^{\mathrm{a}, \mathrm{b}} ; 974 \mathrm{ppb}\right)$, lead $(\mathrm{Pb} ; 1402$ $\mathrm{ppb})$ and cadmium $\left(\mathrm{Cd}^{\mathrm{a}} ; 995.8 \mathrm{ppb} / \mathrm{Cd}^{\mathrm{a}, \mathrm{b}}\right.$; $995.5 \mathrm{ppb}$ ) when compared to starch isolated from cultivar Bread Wheat Misr 1 which recorded $1090 \mathrm{ppb}, 422.6 \mathrm{ppb} / 359.2 \mathrm{ppb}$, $1017 \mathrm{ppb}$ and $992.7 \mathrm{ppb} / 992.6 \mathrm{ppb}$, for the same elements, respectively. On the other hand, cultivar Bread Wheat Misr 1 recorded higher nickel content (3270 ppb) compared to cultivar

Table (3). Quantitative analysis of undesired elements (ppb).

\begin{tabular}{lccccccc}
\hline Wheat cultivar & $\mathbf{C r}^{\mathbf{a}}$ & $\mathbf{N i}^{\mathbf{a}}$ & $\mathbf{A s}$ & $\mathbf{A s}$ & $\mathbf{P b}^{\mathbf{a}}$ & $\mathbf{C d}^{\mathbf{a}}$ & $\mathbf{C d}^{\mathbf{a}, \mathbf{b}}$ \\
\hline Durum BeniSuef 1 & 1196 & 3076 & 998.3 & 974 & 1402 & 995.8 & 995.5 \\
Bread Wheat Misr 1 & 1090 & 3270 & 422.6 & 359.2 & 1017 & 992.7 & 992.6 \\
\hline
\end{tabular}

${ }^{a}$ Measured with graphite technique

${ }^{\mathrm{b}}$ Measured using PO correction model 
Marwa M. A. Mahrous et al.

\subsection{Concentration ofsome nutritive and other elements in isolated starches}

Table (4) Shows the concentration of some nutritive elements which have a specific biochemical function in humans, animals and plants beside other elements. Of the useful nutritive elements sodium $(\mathrm{Na})$, potassium $(\mathrm{K})$, phosphorus $(\mathrm{P})$, magnesium $(\mathrm{Mg})$, calcium $(\mathrm{Ca})$, Manganese $(\mathrm{Mn})$, iron $(\mathrm{Fe})$, copper $(\mathrm{Cu})$, zinc $(\mathrm{Zn})$ and Selenium (Se) and molybdenum (Mo). Cobalt (Co), is available for use by animals only after having been processed into complex molecules (e.g., vitamin B12) by bacteria. Other elements, like Tin (Sn) and antimony concentrations $(\mathrm{Sb})$ are also shown in Table 4.Copper $(\mathrm{Cu})$ concentration was measured by two graphite techniques, one of them is the direct graphite measurement $\left(\mathrm{Cu}^{\mathrm{a}}\right)$ and the other is measurement after compensation of interfering PO signal via correction model $\left(\mathrm{Cu}^{\mathrm{a}, \mathrm{b}}\right)$ which is more precise and of best accuracy.

Table (4). Concentration of some nutritive elements and other elements in isolated starches.

\begin{tabular}{|c|c|c|c|c|c|c|c|c|c|c|c|c|c|c|c|}
\hline $\begin{array}{l}\text { Wheat } \\
\text { cultivar }\end{array}$ & $\begin{array}{c}\mathrm{Na}^{\mathrm{c}} \\
(\mathrm{ppm})\end{array}$ & $\begin{array}{c}\mathrm{K}^{\mathrm{c}} \\
(\mathrm{ppm})\end{array}$ & $\begin{array}{c}\mathrm{P}^{\mathrm{d}} \\
(\mathrm{ppm})\end{array}$ & $\begin{array}{l}\mathrm{Mg}^{\mathrm{c}} \\
(\mathrm{ppm})\end{array}$ & $\begin{array}{l}\mathrm{Ca}^{\mathrm{c}} \\
(\mathrm{ppm})\end{array}$ & $\begin{array}{l}\mathrm{Mn}^{\mathrm{a}} \\
(\mathrm{ppb})\end{array}$ & $\begin{array}{c}\mathrm{Fe}^{\mathrm{c}} \\
(\mathrm{ppm})\end{array}$ & $\begin{array}{l}\mathrm{Co}^{\mathrm{a}} \\
(\mathrm{ppb})\end{array}$ & $\begin{array}{l}\mathrm{Cu}^{\mathrm{a}} \\
(\mathrm{ppb})\end{array}$ & $\begin{array}{l}\mathrm{Cu}^{\mathrm{a}, \mathrm{b}} \\
(\mathrm{ppb})\end{array}$ & $\begin{array}{c}\mathrm{Zn}^{\mathrm{c}} \\
(\mathrm{ppm})\end{array}$ & $\begin{array}{c}\mathrm{Se}^{\mathrm{a}} \\
(\mathrm{ppb})\end{array}$ & $\begin{array}{l}\mathrm{Mo}^{\mathrm{a}} \\
(\mathrm{ppb})\end{array}$ & $\begin{array}{c}\mathrm{Sn}^{\mathrm{a}} \\
(\mathrm{ppb})\end{array}$ & $\begin{array}{c}\mathrm{Sb}^{\mathrm{a}} \\
(\mathrm{ppb})\end{array}$ \\
\hline $\begin{array}{l}\text { Durum } \\
\text { BeniSuef1 }\end{array}$ & 32.66 & 1.222 & 19.29 & 75.39 & 63.97 & 74.2 & 3.375 & 246.4 & 10210 & 10180 & 104.0 & 1540 & 15150 & 992.7 & 978.7 \\
\hline $\begin{array}{l}\text { Bread Wheat } \\
\text { Misr 1 }\end{array}$ & 79.80 & 4.107 & 16.00 & 52.41 & 39.02 & 31.0 & 1.041 & 271.1 & 410.5 & 380.8 & 91.23 & 1053 & 15570 & 781.9 & 1040 \\
\hline
\end{tabular}

Data in Table (4) reveal that cultivar Durum BeniSuef 1 recorded higher contents of phosphorous (P), magnesium (Mg), calcium $(\mathrm{Ca})$, manganese $(\mathrm{Mn})$, iron $(\mathrm{Fe})$,

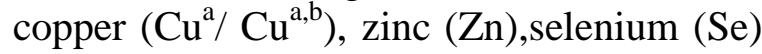
and tin (Sn), being, $19.29 \mathrm{ppm}, 75.39 \mathrm{ppm}$, $63.97 \mathrm{ppm}, 74.2 \mathrm{ppb}, 3.375 \mathrm{ppm}, 10210$ ppb/10180ppb, 104.0 ppm, $1540 \mathrm{ppb} \mathrm{ppb}$ and $992.7 \mathrm{ppb}$, compared to cultivar Bread Wheat Misr 1 which recorded, $16.0 \mathrm{ppm}$, $52.41 \mathrm{ppm}, 39.02 \mathrm{ppm}, 31.0 \mathrm{ppb}, 1.041$ ppm, $410.5 \mathrm{ppb} / 380.8 \mathrm{ppb}, 91.23 \mathrm{ppm}$, $1053 \mathrm{ppb}$ and $781.9 \mathrm{ppb}$, for the same elements, respectively. On the other hand, cultivar Bread Wheat Misr 1 recorded higher contents of sodium $(\mathrm{Na})$, potassium $(\mathrm{K})$, cobalt (Co), molybdenum (Mo) and antimony (Sb), being, 79.80 ppm, 4.107 ppm, $271.1 \mathrm{ppb}, 15570 \mathrm{ppb}$ and $1040 \mathrm{ppb}$, compared to cultivar Durum BeniSuef1,

\subsection{Amylose and Amylopectin in Isolated Starches}

Starch is a mixture of two main components: amylose and amylopectin. which recorded, $32.66 \mathrm{ppm}, 1.222 \mathrm{ppm}$, $246.4 \mathrm{ppb}, 15150 \mathrm{ppb}$ and $978.7 \mathrm{ppb}$, for the same elements, respectively.

Phosphorous which is an important element that could affect functional properties of starches, was reported to be linked in some crops, like potato, in the form of phosphate ester groups (Whistler and $\mathrm{Be}$ Miller, 1997; Takeda et al., 1986). The variation in element concentrations between the studied wheat cultivars is consistent to those reported by Pe'rezet al. (2005) as they reported different concentrations of phosphorous content in Colocasia esculenta [0.01 mg/100g, (equivalent to0.1 ppm)], Xanthosoma sagittifolium $[0.07 \mathrm{mg} / 100 \mathrm{~g}$ (equivalent to0.7 ppm)] and Manihot esculenta $[0.05 \mathrm{mg} / 100 \mathrm{~g}$ (equivalent to0.5 ppm)].

Amylose is essentially a linear polymer consisting of glucose units linked by $\alpha$ $(1 \rightarrow 4)$ glycosidic bonds, slightly branched by $\alpha-(1 \rightarrow 6)$ linkages. Amylopectin is a highly branched polymer constituted of 


\section{Physicochemical studies on starch isolated from Egyptian wheat cultivars}

relatively short branches of $\alpha$-D- $(1 \rightarrow 4)$ glycopyranose that are interlinked by $\alpha$-D$(1 \rightarrow 6)$ glycosidic linkages (Dufresne 2014). Starch contains approximately 20-30\% of amylose which is more soluble in water than the other component amylopectin (70-80\%) (Brown and Poon, 2005). Because of its tightly packed helical structure, amylose is

Table (5) shows the amylose amylopectin pattern of the isolated starches from the studied wheat cultivars. Cultivar Durum BeniSuef 1 recorded higher amylose content (59.84\%) and lower amylopectin content compared to Cultivar Bread Wheat Misr 1 which recorded $46.51 \%$ for amylose and $42.45 \%$ for amylopectin.

The obtained results for the studied cultivars reveals that both cultivars have an more resistant to digestion than other starch molecules and is therefore an important form of resistant starch. The number of repeated glucose subunits (n) is usually in the range of 300 to 3000 , but can be many thousands

(Wikipedia;https://en.wikipedia.org/wiki/A mylose).

amylose-amylopectin profile moderate between normal wheats and waxy ones. The ratio of amylose to amylopectin content in starch varies was reported to be depended on botanical source; normal wheat starches consist of 22-35\% amylose and 65-78\% amylopectin, but the waxy (amylose-free) wheat starches contain essentially $100 \%$ amylopectin (CaiandShi, 2010).

Table (5). Amylose and amylopectin contents in isolated starches.

\begin{tabular}{lll}
\hline Wheat cultivar & Amylose $(\%)$ & Amylopectin $(\%)$ \\
\hline Durum BeniSuef 1 & 59.84 & 26.91 \\
Bread Wheat Misr 1 & 46.51 & 42.45 \\
\hline
\end{tabular}

In biochemical transformations through the plant, and after the production of ADP-glucose by ADP-glucose pyrophosphorylase (AGPase), the "waxy" proteins (granule bound starch synthase I) encoded by the Wx genes are solely responsible for amylose synthesis (reviewed inTetlow, 2006). In contrast, amylopectin synthesis involves a host of enzymes such as starch synthases (SS) I, II, III, IV, starch branching enzymes (SBE) I and II, and starch de-branching enzymes (reviewed in Tetlow, 2006).Several starch biosynthetic proteins remain bound to the interior of starch granules with a subset of these proteins designated the starch granule proteins (SGPs). Using SDS-PAGE, Yamamori and Endo (1996) separated the SGPs from bread wheat starch into SGP-1, SGP-2, SGP-3 and WX. The SGP-1 fraction was further resolvedinto SGP-A1, SGP-B1, and SGP-D1 and the associated genes localized to the homoeologous group 7 chromosomes (Yamamori and Endo, 1996). SGP-1 proteins are isoforms of SSII encoded by the genes SSIIa-A, SSIIa-B, SSIIa-D on the short arms of group 7 chromosomes (Li et al., 1999).A survey of hexaploid wheat germ plasm identified lines lacking SGP-A1, SGP-B1, or SGP-D1 (Yamamori and Endo, 1996) which were crossed to create an SGP-1 null (Yamamori et al., 2000). The SGP-1 null had a $29 \%$ increase in amylose content (37.3\% null vs. $28.9 \%$ wild-type), deformed starch granules, reduced starch content, and reduced binding of SGP-2 and SGP-3 to starch granules. These SGP-1 mutations were later shown to reduce starch binding without impacting SGP protein expression levels (KosarHashemi et al., 2007). Lafiandra et al. (2010) reported that SGP-1 null lines created 
Marwa M. A. Mahrous et al.

from crosses between the Durum (Triticum turgidum ssp. Durum) cultivar 'Svevo' and hexaploid SGP-A1/B1 null lines (Yamamori and Endo, 1996) had an 89\% increase in amylose content compared to Svevo (43.6\% SGP-1 null vs $23 \%$ wild-type) as well as reduced binding of SGP-2 and SGP-3. Elimination of Sbella in Durum through RNA interference also resulted in increased amylase ranging from $+29 \%$ to $+200 \%$ (24\% wild-type vs. $31-75 \%$ SbeIIa RNAi lines) (Sestili et al., 2010). The very high amylose results observed by Sestili et al. (2010) may not be due solely to SbeIIa expression reduction since Sbella mutants have amylose level increases similar to those of SSIIa mutations (28\% sbeIIa versus $23 \%$ wild-type) (Hazard et al., 2012).

\section{6. $\mathrm{pH}$ of the isolated starches}

$\mathrm{pH}$ values of the isolated starches were found to be acidic (less than $\mathrm{pH} 7$ ) recording 3.11 and 3.45 for cultivars Durum BeniSuef 1and Bread Wheat Misr 1, respectively (Table 6). This is consistent to reported data of $\mathrm{pH}$ of different starches separated from crops at different locations (Kaur et al., 2007).

Table (6). pH of the isolated starches.

\begin{tabular}{ll}
\hline Wheat cultivar & $\mathrm{pH}$ \\
\hline Durum BeniSuef 1 & 3.11 \\
Wheat (Bread Wheat Misr 1 & 3.45 \\
\hline
\end{tabular}

\subsection{Hydrolysable effect of short time alkali treatment on the isolated starches}

The isolated starches were heated at reflux temperature in diluted ethanolic sodium hydroxide solution for 15 minutes. It is clear from the Table (7) that both cultivars have close hydrolysable and resistant starch content. Thus, cultivar Durum BeniSuef 1 recorded slightly lower hydrolysable starch content and higher resistant starch content being $64.58 \%$ and $65.09 \%$, compared to cultivar Bread Wheat Misr 1 that recorded $22.17 \%$ and $23.87 \%$, for the same analytes, respectively.

Table (7). Effect of ca. $0.9 \mathrm{M}$ sodium hydroxide on the amount of hydrolysable carbohydrate.

\begin{tabular}{llll}
\hline Wheat cultivar & $\begin{array}{c}\text { Hydrolysable Starch } \\
(\%)\end{array}$ & $\begin{array}{l}\text { Resistant Starch } \\
(\mathbf{R S})(\boldsymbol{\%})\end{array}$ & RS \% to Total Starch (\%) \\
\hline Durum BeniSuef 1 & 64.58 & 22.17 & 25.56 \\
Bread Wheat Misr 1) & 65.09 & 23.87 & 26.83 \\
\hline
\end{tabular}

\subsection{Water binding capacity of the isolated starches}

The water binding capacity (WBC) of the isolated starched (Table 8) reveals that cultivar Durum BeniSuef 1 recorded the higher value being $123.67 \%$, compared to cultivar Bread Wheat Misr 1, which recorded $62.60 \%$.
Sandhu et al. (2004) reported a range of $96 \%$ to $107 \%$ forWBC of starches isolated from different corn types where this difference was attributed to the variation in their granule structure. The differences in degrees of availability of water binding sites among the starches may have also contributed to the variation in WBC (Wotton \& Bamunuarachchi, 1978). 
Table (8). Water binding capacity of the isolated starches

\begin{tabular}{ll}
\hline Wheat cultivar & Water Biding Capacity (WBC) (\%) \\
\hline Durum BeniSuef 1 & 123.67 \\
Bread Wheat Misr 1 & 62.60 \\
\hline
\end{tabular}

1.9. Solubility of the Isolated Starched and Temperature Effect on It

Solubility of the isolated starches (Table 9) was studied at three different temperatures $30^{\circ} \mathrm{C}, \quad 60^{\circ} \mathrm{C}$ and $95^{\circ} \mathrm{C}$, respectively. At $30^{\circ} \mathrm{C}$ and $60^{\circ} \mathrm{C}$, cultivar Durum BeniSuef 1, recorded the higher solubilities being $2.04 \%, 12.79 \%$, compared to cultivar Bread Wheat Misr 1, which recorded, $0.76 \%$ and $9.96 \%$, at the same temperatures, respectively. On the other hand, at $100{ }^{\circ} \mathrm{C}$, cultivar Bread Wheat Misr 1 recorded the higher solubility being $100 \%$, compared to, cultivar Durum BeniSuef 1, which recorded $73.85 \%$, at the same temperature.

Table (9). Solubility (\%) of isolated starches.

\begin{tabular}{llll} 
Wheat cultivar & Solubility $(\%)$ at $30^{\circ} \mathrm{C}$ & Solubility (\%) at $60^{\circ} \mathrm{C}$ & $\begin{array}{l}\text { Solubility (\%) at } \\
95^{\circ} \mathrm{C}\end{array}$ \\
\hline Durum BeniSuef 1 & 2.04 & 12.79 & 73.85 \\
Bread Wheat Misr 1 & 0.76 & 9.96 & 100 \\
\hline
\end{tabular}

1.10. Swelling power of the isolated starched and temperature effect on it

The swelling power $(\mathrm{g} / \mathrm{g})$ of the isolated starches from the studied cultivars was studied at three different temperatures as shown in Table (10). Thus, at all the studied temperatures; $30^{\circ} \mathrm{C}, 60^{\circ} \mathrm{C}$ and $95^{\circ} \mathrm{C}$, starch isolated from cultivar Durum BeniSuef 1, recorded the higher swelling power, being $6.60 \mathrm{~g} / \mathrm{g}, 9.95 \mathrm{~g} / \mathrm{g}$ and $14.5 \mathrm{~g} / \mathrm{g}$, compared to starch isolated from cultivar Durum BeniSuef 1, which recorded, 6.07 $\mathrm{g} / \mathrm{g}, 9.87 \mathrm{~g} / \mathrm{g}$ and $10.31 \mathrm{~g} / \mathrm{g}$, respectively.

Table (10). Swelling power (g/g) of isolated starches.

\begin{tabular}{llll}
\hline Wheat cultivar & $\begin{array}{l}\text { Swelling power }(\mathrm{g} / \mathrm{g}) \\
\text { at } 30{ }^{\circ} \mathrm{C}\end{array}$ & $\begin{array}{l}\text { Swelling power }(\mathrm{g} / \mathrm{g}) \\
\text { at } 60^{\circ} \mathrm{C}\end{array}$ & $\begin{array}{l}\text { Swelling power }(\mathrm{g} / \mathrm{g}) \\
\text { at } 95^{\circ} \mathrm{C}\end{array}$ \\
\hline Durum BeniSuef 1 & 6.60 & 9.95 & 14.50 \\
Bread Wheat Misr1 & 6.07 & 9.87 & 10.31 \\
\hline
\end{tabular}

Studying the swelling power in comparison with the water binding capacity led to interesting finding. The wheat cultivar, Durum BeniSuef 1, of higher water binding capacity (123.67\%), recorded the higher swelling power, under all studied heat temperatures.
Thus, it was concluded that swelling power of starch depends on water holding capacity of starch molecules via hydrogen bonding consistent to that published by Lee and Osman (1991). Hydrogen bonds stabilizes the structure of the double helices in crystallites are broken during gelatinization and are replaced by the 
Marwa M. A. Mahrous et al.

hydrogen bonds with water, and swelling is regulated by the crystallinity of the starch

\subsection{Fourier Transform Infrared (FT-IR) Spectroscopy of Isolated Starches}

Figures (1a,b \& 2 a,b) and Tables (11 \& 12) indicated the FT-IR spectral data of the isolated starches in comparison with that of amylose (Fig.3a,b) in the frequency region 4000-400 $\mathrm{cm}^{-1}$. Cultivar Durum BeniSuef 1 (Figs. 1a,b, Table 11), recorded characteristic bands at; $3370 \mathrm{~cm}^{-1}(\mathrm{OH}$ band), $2931 \mathrm{~cm}^{-1}$ (CH stretching vibrations), $1649 \mathrm{~cm}^{-1}$ (due totightly bound water present in the starch granule),1156, 1081, 1020, $930 \mathrm{~cm}^{-1} \quad$ (C-Obondstretching vibrations in the finger print region). On the other hand, cultivar Bread Wheat Misrl(Figs. 2a,b, Table 12), recorded similar bands at $3365 \mathrm{~cm}^{-1}(\mathrm{OH}$ band), $2932 \mathrm{~cm}^{-1}$ (CH stretching vibrations), 1647 $\mathrm{cm}^{-1}$ (due totightly bound water present in the starch granule), 1152, 1080, 1029, $928 \mathrm{~cm}^{-1}$ (C-Obondstretching vibrations in the finger print region).The obtained spectral data are consistent to those reported for
(Tester and Karkalas, 1996).

native and modified potato starch (Fang et al., 2004; Hui et al., 2009). The great similarity between the spectra of the studied cultivars and amylose may assure the high levels of amylose in both cultivars (Fig. 3a). The difference in spectral data between the studied cultivars and amylose appears in the frequency regions of $500-400 \mathrm{~cm}^{-1}$ (Fig. 3b).

The FT-IR spectrum of starch is sensitive to changes in structure of a shortrange molecular level (double helices). The absorbance bands at 1022 and $1047 \mathrm{~cm}^{-1}$ are characteristics of amorphous and ordered structures in starch (Van Soest et al. 1995). Thus, the ratio of $1047 \mathrm{~cm}^{-1} / 1022 \mathrm{~cm}^{-1}$ can be used to characterize the short-range molecular order of double helices in starches (Van Soest et al., 1995; Capron et al., 2007). Figures $(4,5)$ show the absorbance bands at 1047 and $1022 \mathrm{~cm}^{-1}$ of starches isolated fromcultivars Durum BeniSuef 1 and which confirms different amorphous and ordered structures between them.

\begin{tabular}{lll}
\hline $\begin{array}{l}\text { Table (11) Infrared spectroscopy transmittance }(\% \mathbf{T}) \text { at different frequencies }\left(\mathbf{C m}^{-\mathbf{1}}\right) \text { of wheat } \\
\text { BeniSuef } \mathbf{~ ( ~}) \text {. }\end{array}$ \\
\hline Purum \\
1 & $\mathrm{X}\left(\right.$ Frequency; $\left.\mathrm{cm}^{-1}\right)$ & $\mathrm{Y}(\% \mathrm{~T})$ \\
2 & 3369.52 & 19.33 \\
3 & 2931.1 & 40.39 \\
4 & 2151.63 & 82.16 \\
5 & 1649.38 & 43.74 \\
6 & 1416.34 & 42.42 \\
7 & 1369.75 & 41.6 \\
8 & 1240.91 & 47.72 \\
9 & 1156.23 & 20.25 \\
10 & 1080.71 & 17.56 \\
11 & 1019.63 & 11.06 \\
12 & 929.72 & 50.67 \\
13 & 860.82 & 61.06 \\
14 & 764.27 & 49.69 \\
15 & 708.54 & 45.75 \\
& 575.14 & 33.73
\end{tabular}




\section{Physicochemical studies on starch isolated from Egyptian wheat cultivars}

Table (11) Infrared spectroscopy transmittance $(\% \mathrm{~T})$ at different frequencies $\left(\mathrm{Cm}^{-1}\right)$ of wheat ( Durum BeniSuef 1).

\begin{tabular}{lll}
\hline 16 & 526.93 & 36.97 \\
17 & 499.17 & 38.79 \\
18 & 487.62 & 41.31 \\
19 & 480.06 & 28.55 \\
20 & 471.74 & 21.77 \\
21 & 460.97 & 69.21 \\
22 & 450.84 & 29.22 \\
23 & 444.86 & 65.78 \\
24 & 436.86 & 73.14 \\
25 & 427.93 & 74.28 \\
26 & 421.6 & 86.73 \\
27 & 408.17 & 74.96 \\
28 & 403.97 & 67.85 \\
\hline
\end{tabular}

Table (12) Infrared spectroscopy transmittance (\% T) at different frequencies $\left(\mathrm{Cm}^{-1}\right)$ of wheat (Bread Wheat Misr 1)

\begin{tabular}{lll}
\hline \hline Peak Number & $\mathrm{X}\left(\mathrm{cm}^{-1}\right)$ & $\mathrm{Y}(\% \mathrm{~T})$ \\
\hline 1 & 3365.28 & 0.25 \\
2 & 2931.55 & 2.07 \\
3 & 2150.79 & 32.36 \\
4 & 1647.06 & 6.43 \\
5 & 1458.88 & 3.55 \\
6 & 1416.35 & 2.98 \\
7 & 1368.66 & 2.5 \\
8 & 1242.2 & 4.51 \\
9 & 1151.85 & 0.28 \\
10 & 1080.17 & 0.15 \\
11 & 1028.5 & 0.05 \\
12 & 1006 & 0.05 \\
13 & 928.26 & 4.54 \\
14 & 860.83 & 8.53 \\
15 & 763.85 & 4.33 \\
16 & 708.44 & 3.35 \\
17 & 672.78 & 3.97 \\
18 & 667.37 & 3.93 \\
19 & 656.43 & 3.53 \\
20 & 640.44 & 3.04 \\
21 & 626.39 & 2.54 \\
22 & 618 & 2.16 \\
23 & 611 & 2.16 \\
24 & 605.32 & 2.13 \\
25 & 590.73 & 1.47
\end{tabular}


Marwa M. A. Mahrous et al.

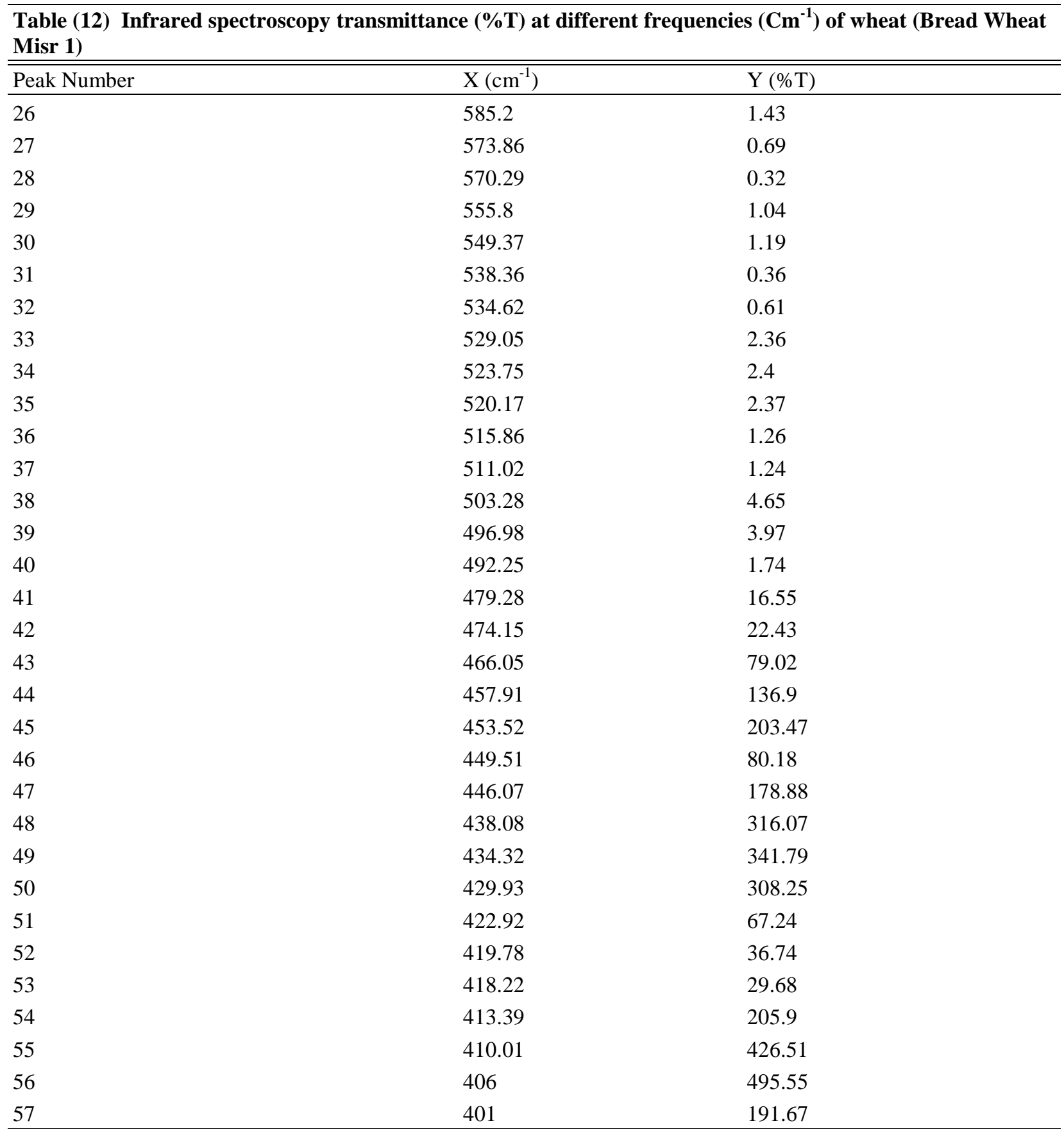


Physicochemical studies on starch isolated from Egyptian wheat cultivars

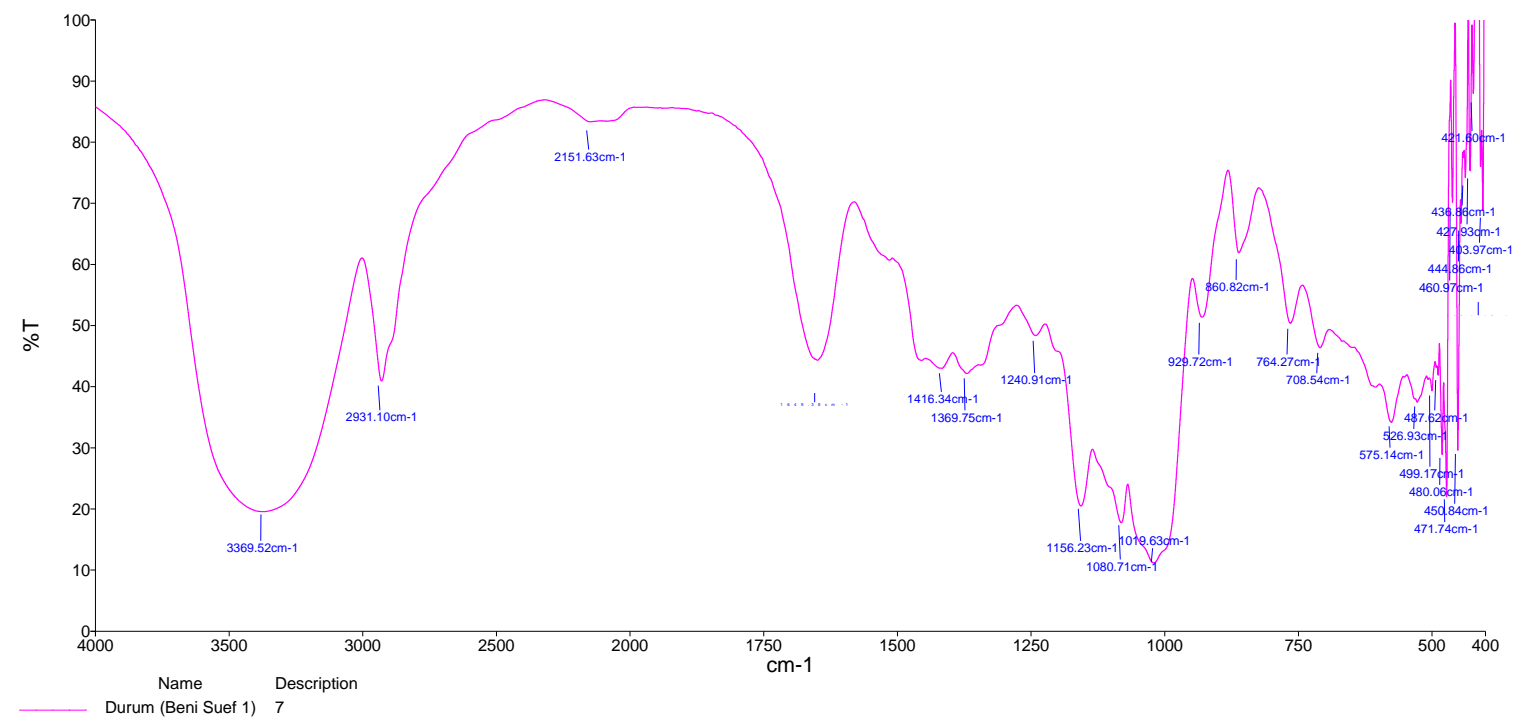

Fig. (1a) . FT-IR spectrum of wheat (Durum BeniSuef 1) starch in the region $4000-400 \mathrm{~cm}^{-1}$

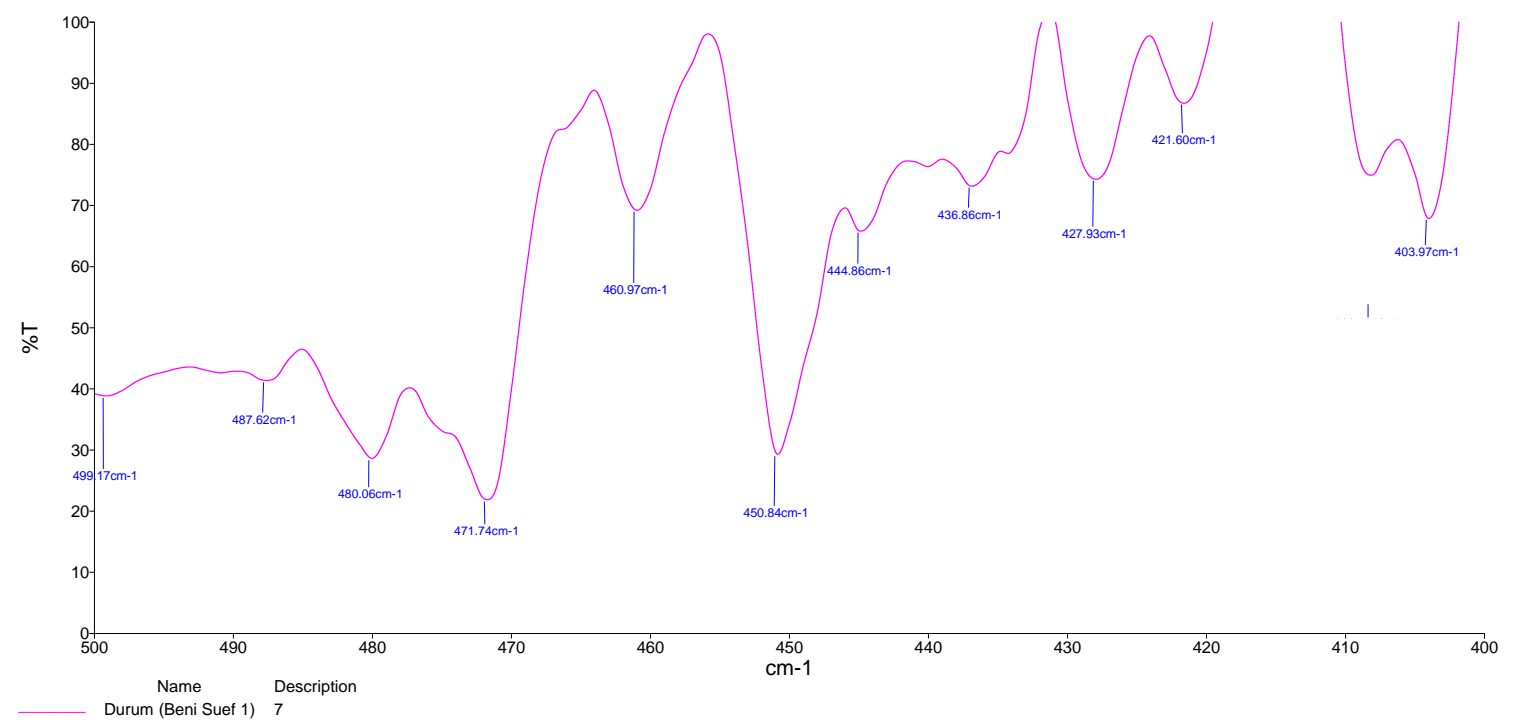

Fig. (1b). FT-IR spectrum of wheat (Durum BeniSuef 1) starch in the region $500-400 \mathrm{~cm}^{-1}$ 
Marwa M. A. Mahrous et al.

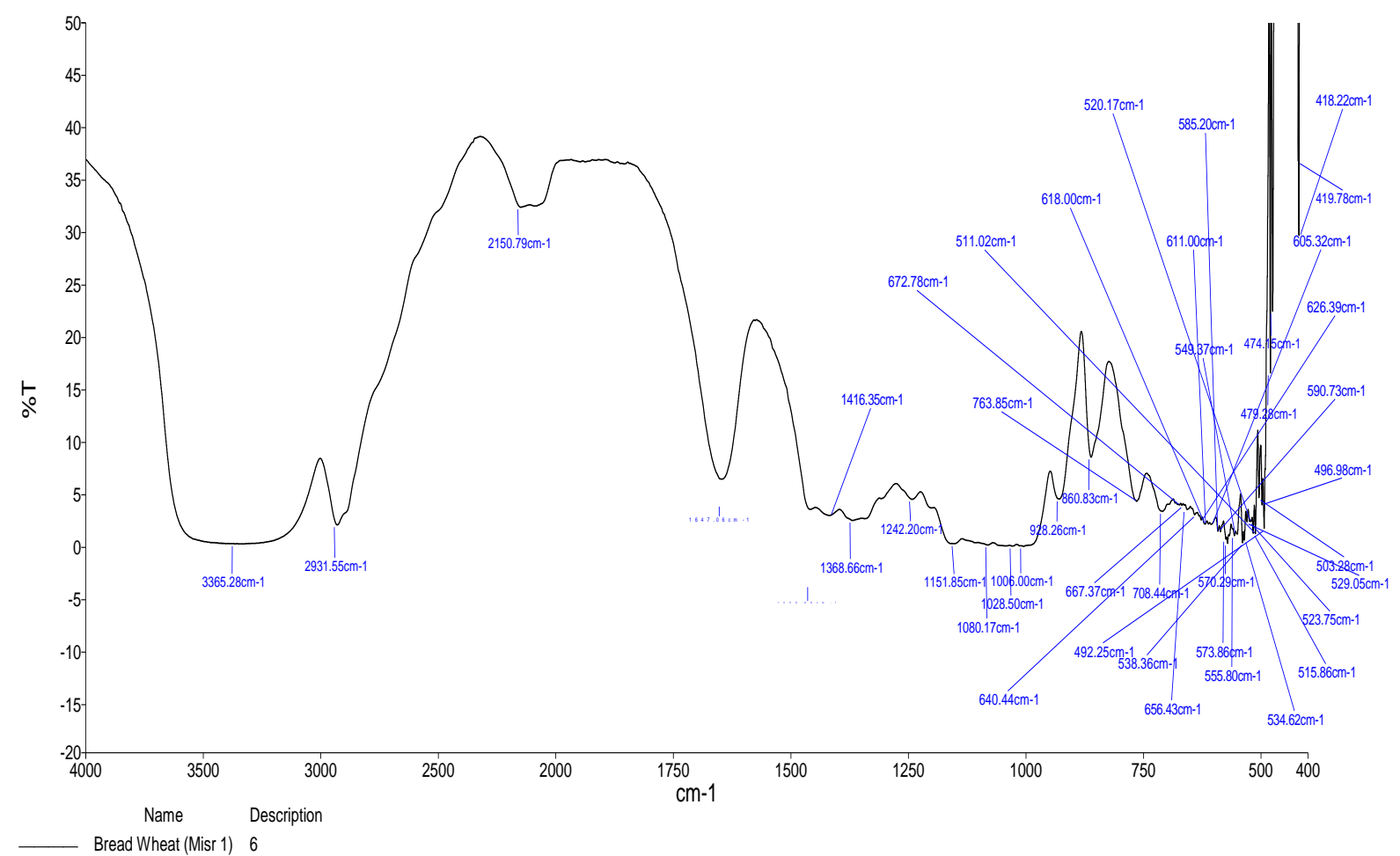

Fig. (2a). FT-IR spectrum of wheat (Bread Wheat Misr 1) starch in the region $4000-400 \mathrm{~cm}^{-1}$

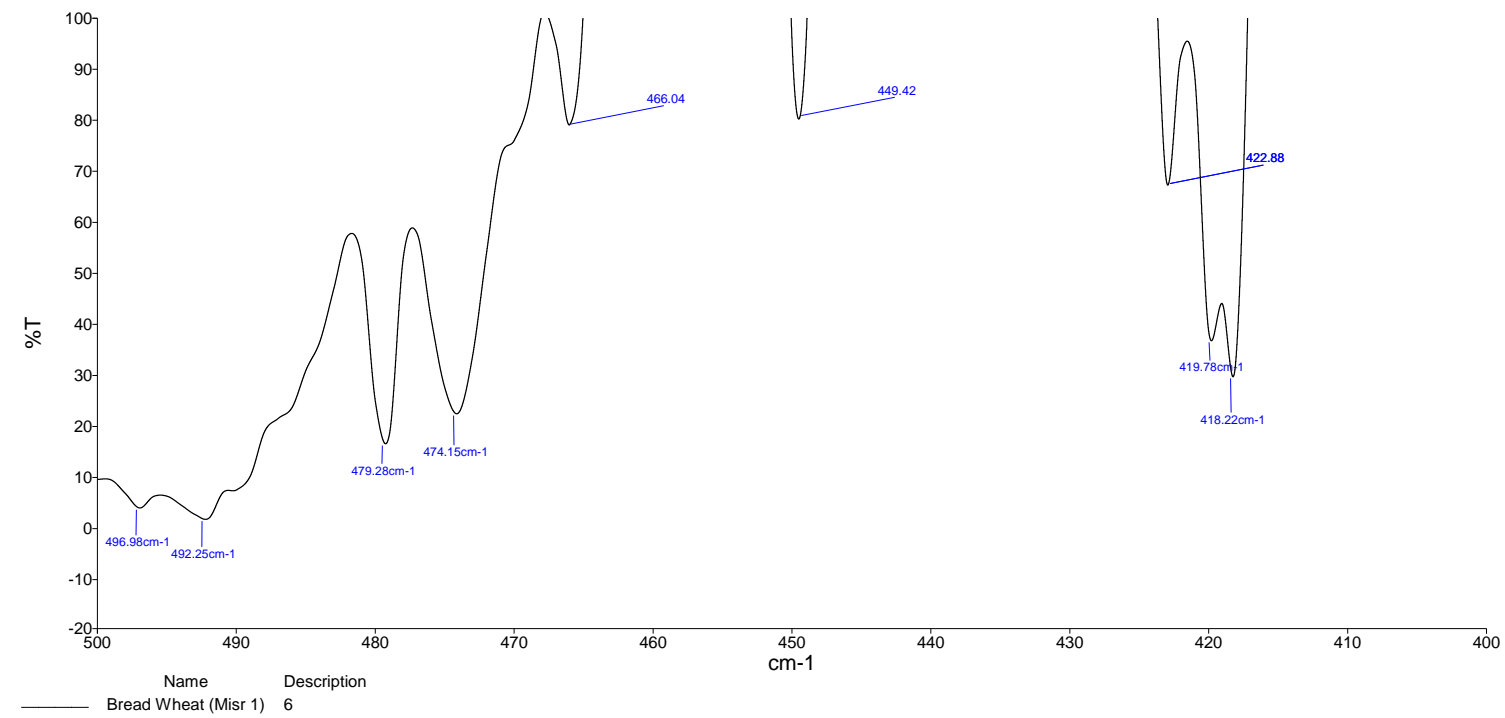

Fig. (2b) FT-IR spectrum of wheat (Bread Wheat Misr 1) starch in the region $500-400 \mathrm{~cm}^{-1}$ 
Physicochemical studies on starch isolated from Egyptian wheat cultivars

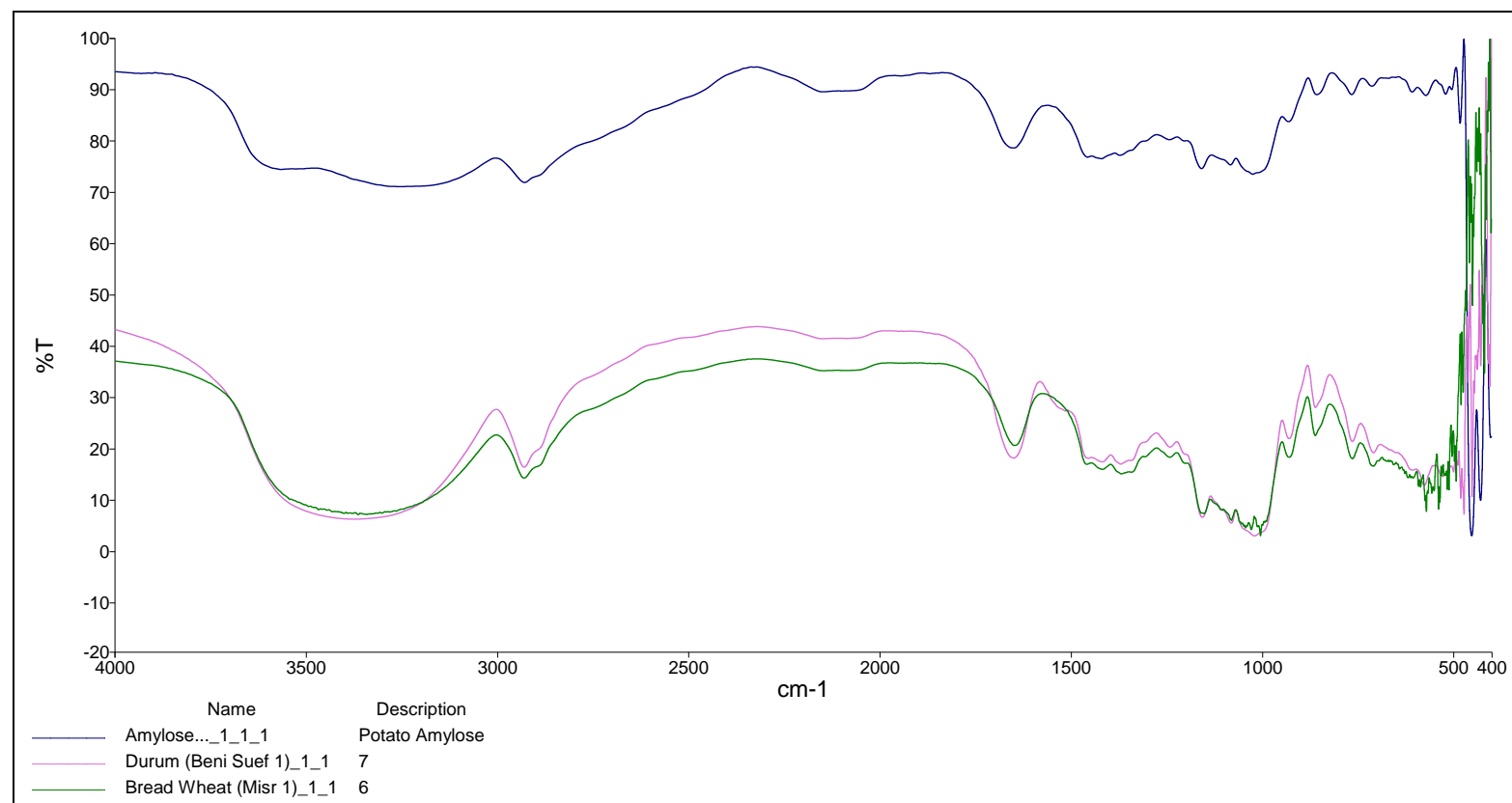

Fig. (3a). Overlaid spectra of potato amylose andstarches isolated fromcultivarsDurum BeniSuef 1 and Bread Wheat Misr 1 in the region $4000-400 \mathrm{~cm}^{-1}$

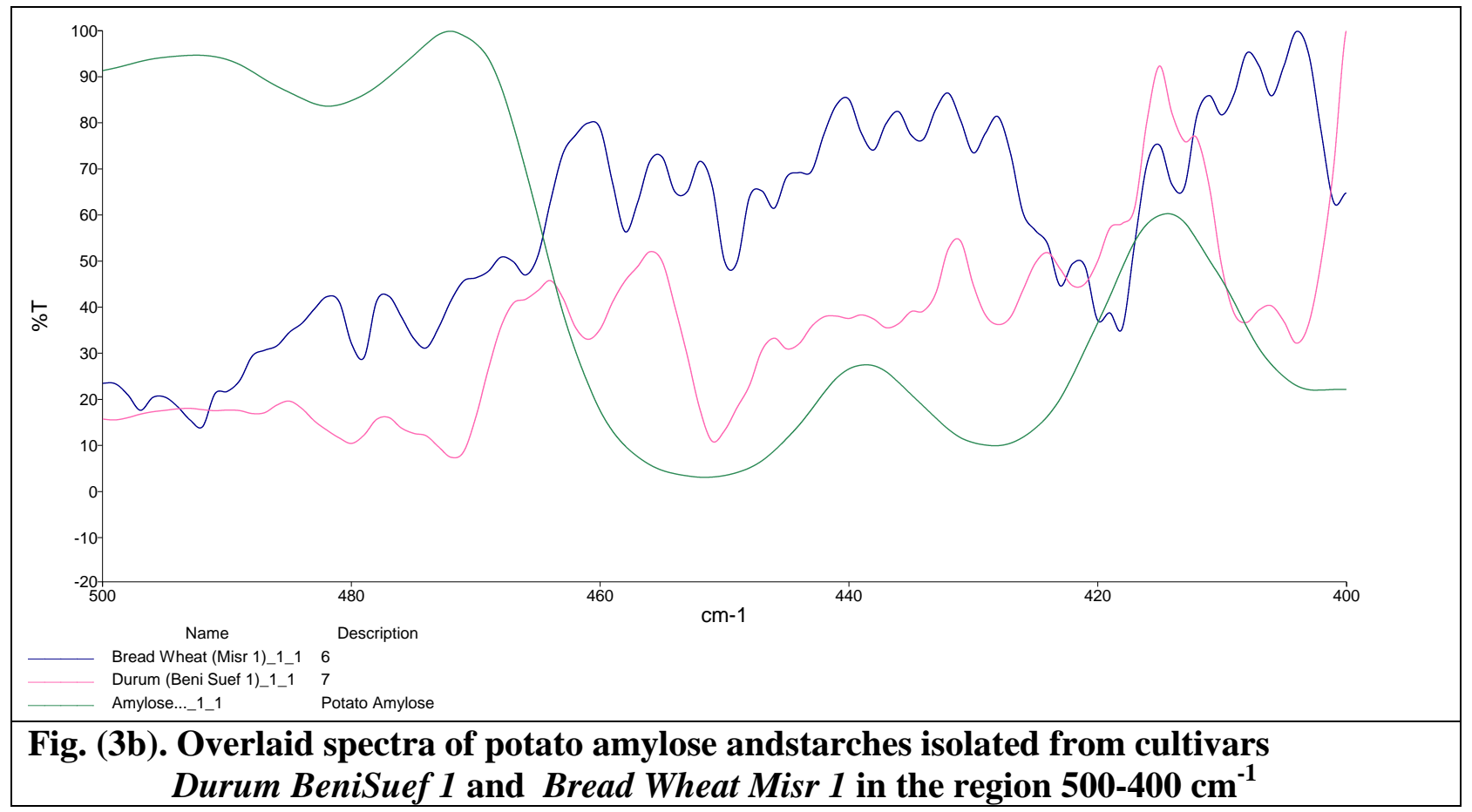


Marwa M. A. Mahrous et al.

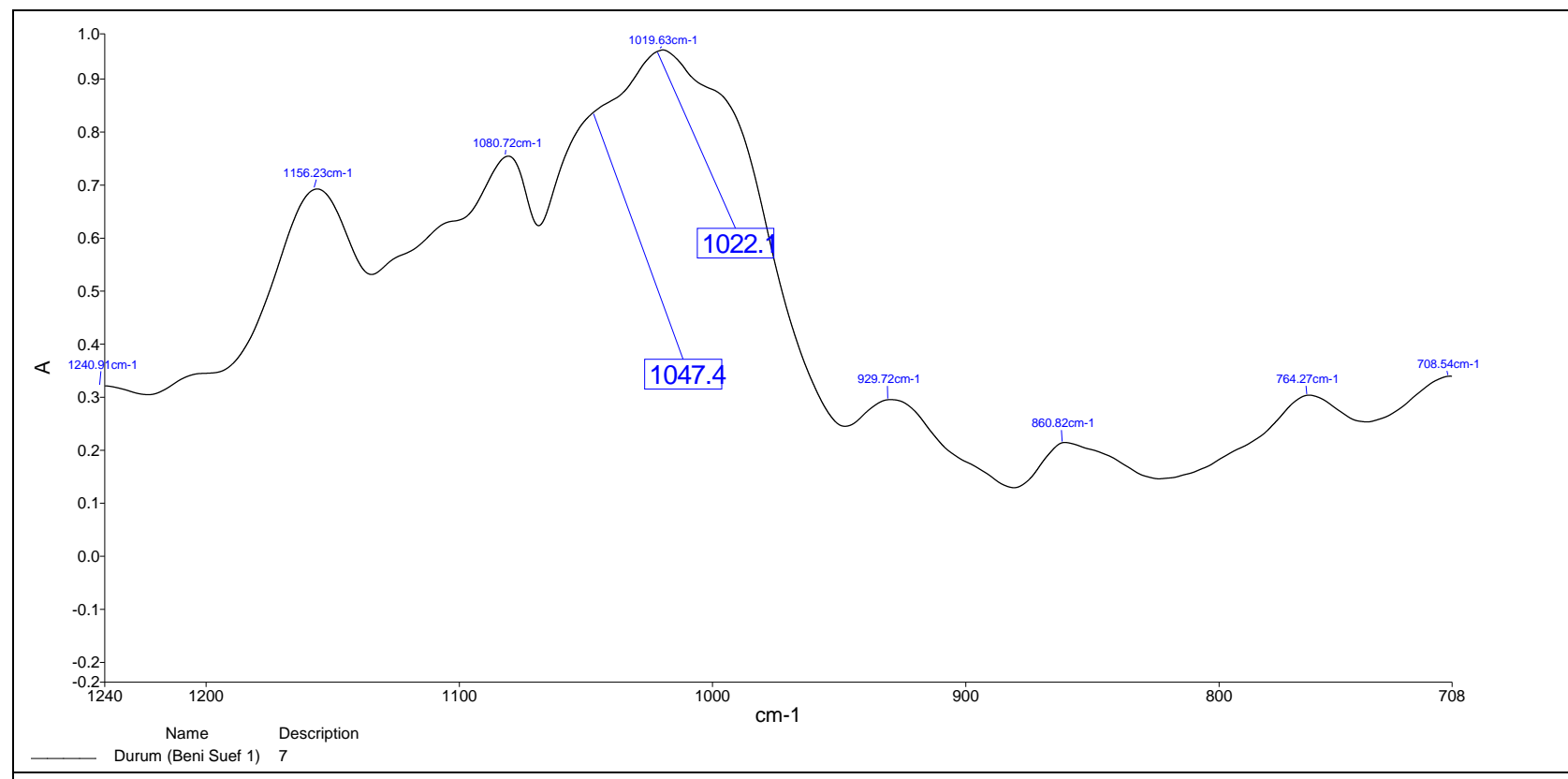

Fig. (4) FT-IR absorbance bands of starch isolated from cultivar Durum BeniSuef 1 at 1047 and $1022 \mathrm{~cm}^{-1}$

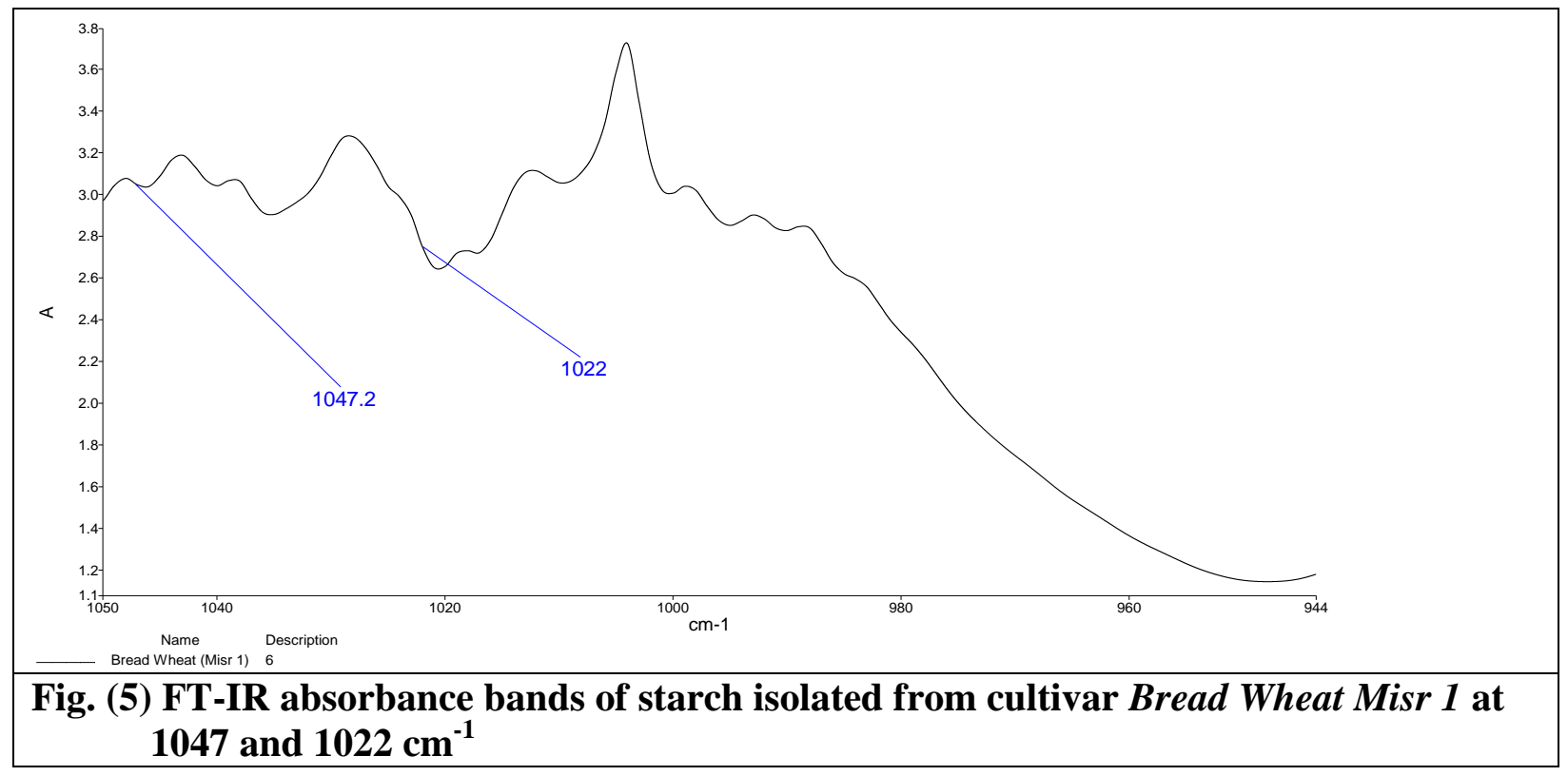

\subsection{X-Ray diffraction pattern of isolated} starches:

The X-ray diffraction pattern of the crystal structure of the isolated starches are summarized in Figures (6a,b) and Tables $(13,14)$. Starch isolated from cultivar
Durum BeniSuef1 exhibited single peaks at $2 \theta=14.86^{\circ}, 17.05^{\circ}, 18.29^{\circ}, 23.38^{\circ}$, while starch isolated from cultivar Bread Wheat Misr 1 revealed similar peaks at $2 \theta=15.17^{\circ}$, $17.07^{\circ}, 18.17^{\circ}, 23.37^{\circ}$, showing the typical characteristics of an A-type diffraction 
Physicochemical studies on starch isolated from Egyptian wheat cultivars

pattern. Similar close diffraction pattern of al., 2013).

A-type was previously reported (Zhang et

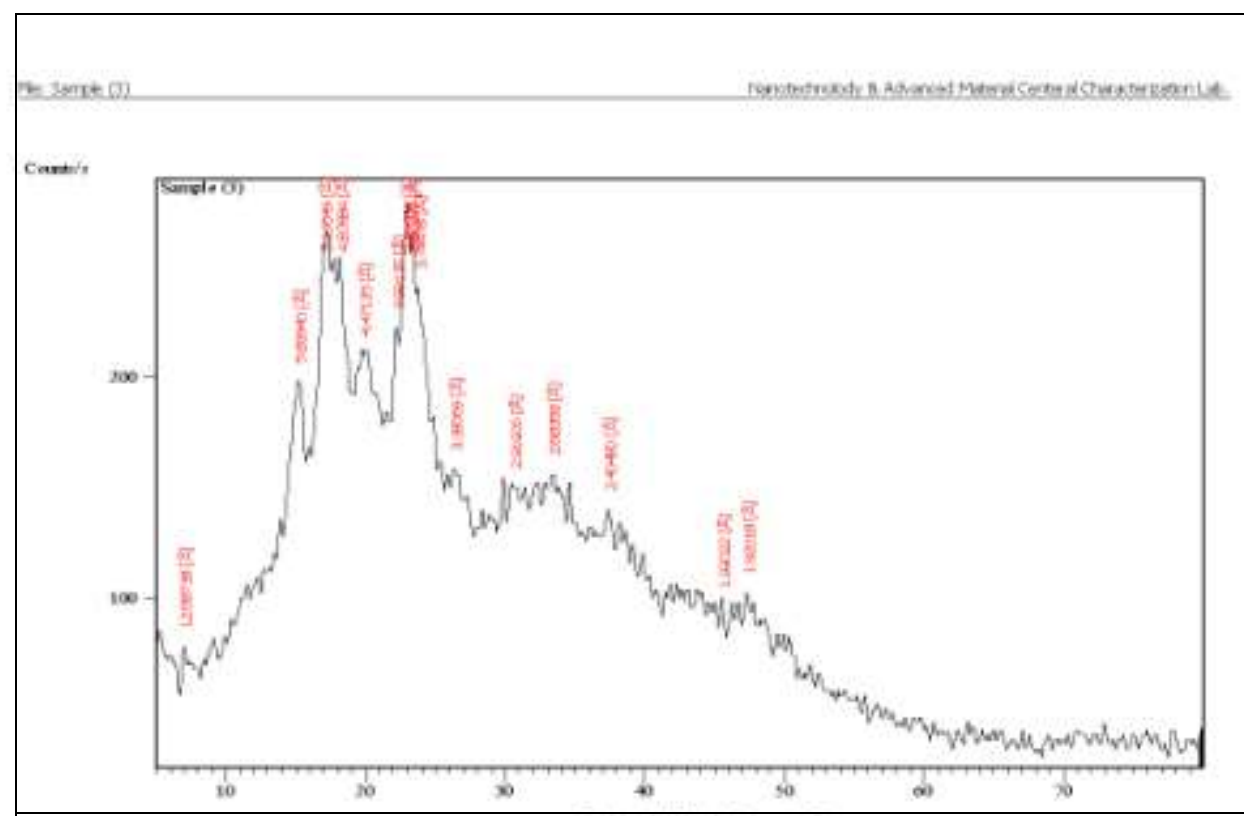

Fig. (6b). X-Ray diffraction pattern of wheat' ( Bread Wheat Misr 1) starch

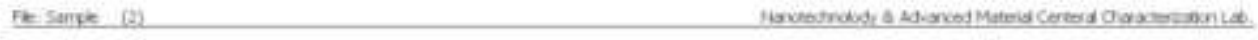

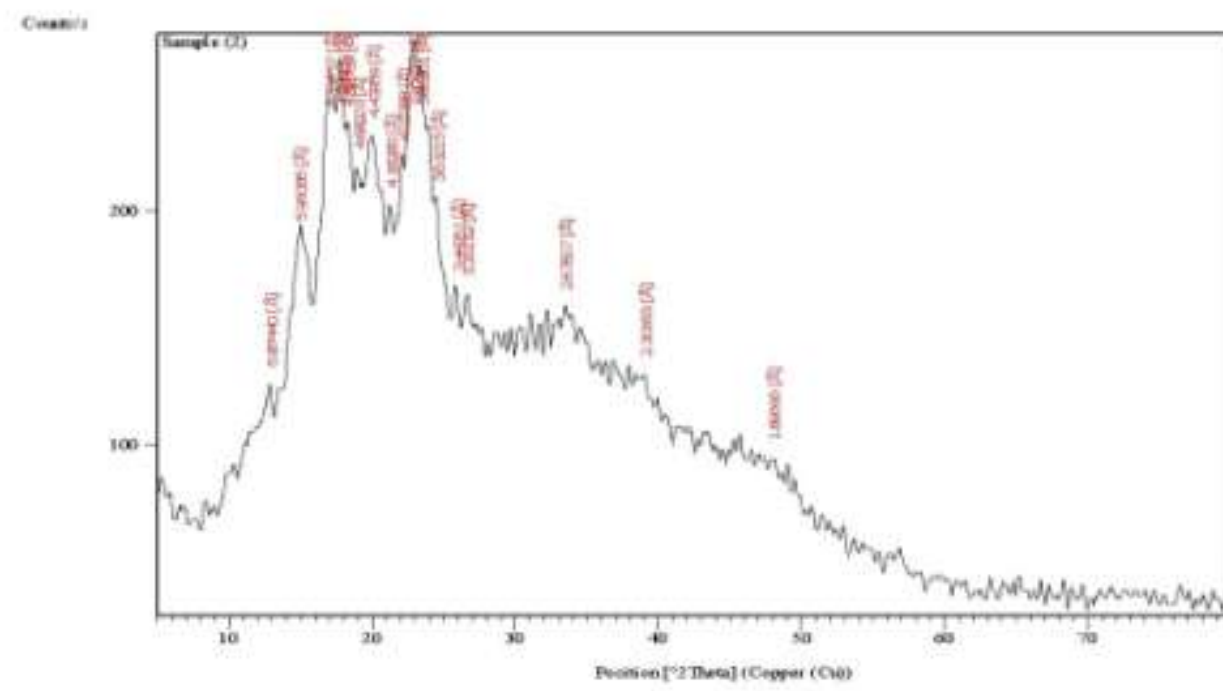

The IM

Fig, (6a). X-Ray diffraction pattern of wheat (Durum BeniSuef 1) starch 


\begin{tabular}{llllll}
\multicolumn{6}{l}{ Table 14. X-ray diffraction data of starch isolated from cultivar Bread Wheat Misr 1 } \\
\hline No. & Pos. $\left[{ }^{\circ}\right.$ 2Th.] & d-spacing [Å] & Height [cts] & Height [cps] & Rel. Int. [\%] \\
\hline 1 & 6.9616 & 12.68738 & 3.63 & 7.25 & 7.9 \\
2 & 15.1731 & 5.8394 & 23.88 & 47.75 & 52.02 \\
3 & 17.0668 & 5.19549 & 35.47 & 70.94 & 77.28 \\
4 & 18.1684 & 4.87884 & 22.28 & 44.55 & 48.54 \\
5 & 19.8401 & 4.47135 & 2.59 & 5.18 & 5.65 \\
6 & 22.2549 & 3.99135 & 18.85 & 37.7 & 41.07 \\
7 & 22.9472 & 3.87568 & 45.9 & 91.79 & 100 \\
8 & 23.3694 & 3.80347 & 38.32 & 76.63 & 83.48 \\
9 & 23.7409 & 3.74478 & 25.8 & 51.61 & 56.22 \\
10 & 26.3414 & 3.38069 & 1.98 & 3.95 & 4.3 \\
11 & 30.6015 & 2.91906 & 1.31 & 2.62 & 2.85 \\
12 & 33.3618 & 2.68358 & 2.45 & 4.89 & 5.33 \\
13 & 37.3642 & 2.4048 & 4.93 & 9.86 & 10.74 \\
14 & 45.5809 & 1.99022 & 2.66 & 5.32 & 5.8 \\
15 & 47.3014 & 1.92018 & 4.7 & 9.41 & 10.25 \\
\hline
\end{tabular}

REFERENCES

AOAC (2012).

Analysis of AOAC International, $19^{\text {th }}$ edn.

AOCS official procedure: Rapid determination of oil/fat utilizing high temperature solvent extraction. ANKOM Technology method, 1212-05. Am 5-04, p 24-25.

Brown, W.H. and Poon, T. (2005). Introduction to organic chemistry (3rd ed.). Wiley. ISBN 0-471-444510 .

Cai. L.M. and Shi, Y.C. (2010). Structure and digestibility of crystalline shortchain amylose from debranched waxy wheat, waxy maize, and waxy potato starches. Carbohydrate. Polymers, 9: 1117-1123.

Contr, AA 700 Analytical jena)application notes (manual) and cook book Recommended Conditions for Analytical Methods - contra Graphite Furnace Technique (Aspect CS software)
Official

methods

of
Cummings, J.H.; Beatty, E.R.; Kingman, S.M.; Binghan, S.A. and Englyst, H.N. (1996). Digestion and physiological properties of resistant starch in the human large bowel. British J. Nutr., 75: 733-747.

Directive 2002/32/ec of the European parliament and of the council (2002). Undesirable substances in animal feed. Official J. European Communities, L 140/10.

Dufresne, A. (2014). Crystalline starch based nanoparticles. Current Opinion in Colloid \& Interface Science, 19: 397-408.

Dubois, M.; Giles, K.A.; Hamilton, J.K.; Rebers, P.A. and Smith, F. (1956). Colorimetric method of determination of sugars and related substances. Analytical Chem., 28: 350-356. 


\section{Physicochemical studies on starch isolated from Egyptian wheat cultivars}

Englyst, H.N. and Hudson, G.J. (1996). The classification and measurement of dietary carbohydrates. Food Chem., 57: $15-21$

Fang, J.M.; Fowler, P.A.; Sayers, C. and Williams, P.A. (2004). The chemical modification of a range of starches under aqueous reaction conditions. Carbohydrate Polymers, 55, 283289.

FCO (1985). Fertilizer (Control) Order (No.11-3/83-STU), Ministry of Agriculture and Rural Development (Department of Agriculture and Cooperation) New Delhi, Government of India, $25^{\text {th }}$ September.

Goesaert, H.; Brijs, K.; Veraverbeke, W.S.; Courtin, C.M.; Gebruers, K. and Delcour, J.A. (2005). Wheat flour constituents: how they impact bread quality, and how to impact their functionality . Trends in Food Sci. \& Technol., 16: 12-30.

Han, X.Z.; Ao, Z.; Janaswamy, S.; Jane, J.L.; Chandrasekaran, R. and Hamaker, B.R. (2006). Development of a low glycemic maize starch: Preparation and characterization. Biomacromolecules, 7: 1162-1168.

Hazard, B.; Zhang, X.; Colasuonno, P.; Uauy, C.; Beckles, D.M. and Dubcovsky, J. (2012). Induced mutations in the starch branching enzyme II (SBEII) genes increase amylose and resistant starch content in Durum wheat. Crop Science, 52:1754-1766.

Hui, R.; Qi-he, C.; Ming-liang, F.; Qiong, X. and Guo-qing, H. (2009). Preparation and properties of octenyl succinic anhydride modified potato starch. Food Chem., 114: 81-86.

Hung, P.V.; Maeda, T. and Morita, N. (2006). Waxy and high-amylose wheat starches and flours- characteristics, functionality and application.Trends in Food Science \& Technol., 17: 448-456.

Jenkins, D.J.; Kendall, C.W.; Augustin, L.S.; Franceschi, S.; Hamidi, M.; Marchie, A. and

Axelsen, M. (2002). Glycemic index: Overview of implications in health and disease. Am. J. Clin. Nutr., 76: 266S-273S.

Jobling, S. (2004). Improving starch for food and industrial applications. Current Opinion in Plant Biol., 7: 210-218.

Kaur, A.; Singh, N.; Ezekiel, R. and Guraya, H.S. (2007).Physicochemical, thermal and pasting properties of starches separated from different potato cultivars grown at different locations. Food Chem., 101: 643651.

Kosar-Hashemi, B.; Li, Z.Y.; Larroque, O.; Regina, A.; Yamamori, Y.M.; Morell, M.K/ and Rahman, S. (2007). Multiple effects of the starch synthase II mutation in developing wheat endosperm. Functional Plant Biol., 34: 431-438.

Kozlov, S.S.; Krivandin, A.V.; Shatalova, O.V.; Noda, T.; Bertoft. E.; Fornal, J. and Yuryev, V.P. (2007). Structure of starches extracted from nearisogenic wheat lines.J. Thermal Analysis and Calorimetry, 87:575584.

Kozlov, S.S.; Noda, T.; Bertoft, E. and Yuryev, V.P. (2006). Structure of starches extracted from near-isogenic wheat lines. Part 1. Effect of different GBSS 1 combinations. J. Thermal Analysis and Calorimetry, 86: 291-301.

Lafiandra, D.; Sestili, F.; D’Ovidio, R.; Janni, M.; Botticella, E.; Ferrazzano, G.; Silvestri, M.; Ranieri, R. and DeAmbrogio, E. (2010). Approaches 


\section{Marwa M. A. Mahrous et al.}

for modification of starch composition in Durum wheat. Cereal Chem., 87: 28-34.

Lee, Y.E. and Osman, E.M. (1991). Correlation of morphological changes of rice starch granules with rheological properties during heating in excess water. J. Korean Agric. \& Chem. Soc., 34: 379-385.

Li, Z.; Chu, X.; Mouille, G.; Yan, L.; KosarHashemi, B.; Hey, S.; Napier, J.; Shewry, P.; Clarke, B.; Appels, R.; Morell, M.K. and Rahman, S. (1999). The localization and expression of the class II starch synthases of wheat. Plant Physiol., 120: 1147-1156.

Medcalf, M.J. and Gilles, K.A. (1965). Wheat starches. I. Comparison of physicochemical properties. Cereal Chem., 42: 558-568.

Olsen, B.T. (1994). In: BushukW ,Rasper VF , eds . Wheat: Production, Properties and Quality. London, UK : Chapman and Hall; [Chapter 1]

Pe'rez, E.; Schultzb, F.S. and Pacheco de Delahaye, E. (2005). Characterization of some properties of starches isolated from Xanthosoma sagittifolium (tannia) and Colocassia esculenta (taro). Carbohydrate Polymers, 60: 139145.

Sandhu, K.S.; Singh, N. and Kaur, M. (2004). Characteristics of different corn types and their grain fractions: Physico-chemical, thermal, morphological and rheological properties of starches. J. Food Engineering, 64: 119-127.

Schoch, T.J. (1964). In Whistler R L (Ed.), Methods in Carbohydrate Chemistry, Vol. IV. (pp. 106-108) New York: Academic Press.

Sestili F, Janni M, Doherty A, Botticella E, D'Ovidio R, Masci S, Jones JD,
Lafiandra D, (2010). Increasing the amylose content of Durum wheat through silencing of the SBEIIa genes. BMC Plant Biology 10, 144

Sowbhagya, C.M. and Bhattacharya, K.R. (1971). A simplified colorimetric method for determination of amylose content in rice. Starch, 23: 53-56.

Takeda, Y.; Tokunaga, N.; Takeda, C. and Hizukuri, S (1986). Physicochemical properties of sweet potato starches. Starch/Starke, 38: 345-350

Tester, R.F. and Karkalas, J. (1996). Swelling and gelatinization of oat starches. Cereal Chem., 73: 271-273.

Tester, R.F.; Karkalas, J. and Qi, X. (2004 Starch Composition, Fine Structure and Architecture. J. Cereal Sci., 39: 151-165.

Tetlow, I.J. (2006). Understanding storage starch biosynthesis in plants: a means to quality improvement. Canad. J. Botany, 84: 1167-1185.

Unnikrishnan, K.R. and Bhattacharya, K.R. (1981). Swelling and solubility behaviour of parboiled rice flour. J. Food Technolol., 16: 403-408.

Van Soest, J.J.G.; Tournois, H.; De Wit, D. and Vliegenthart, J.F.G. (1995). Shot-range structure in (partially) crystalline potatostarch determined with attenuated total reflectance Fourier transformIR spectroscopy. Carbohydrate Res., 279: 201-214.

Whistler, R.L. and BeMiller, J.N. (1997). Starch. In: Carbohydrate chemistry for food scientists. Saint Paul, MN, USA: Eagan Press.

Wikipedia: The free encyclopedia;https://en.wikipedia.or $\mathrm{g} /$ wiki/Amylose

Wotton, M. and, Bamunuarachchi, A. (1978). Water binding capacity of commercial produced native and 


\section{Physicochemical studies on starch isolated from Egyptian wheat cultivars}

modified starches. Starch, 33: $159-161$.

Yamamori, M. and End, T.R. (1996). Variation of starch granule proteins and chromosome mapping of their coding genes in common wheat. Theoretical and Applied Genetics, 93: 275-281.

Yamamori, M.; Fujita, S.; Hayakawa, K.; Matsuki, J. and Yasui, T. (2000). Genetic elimination of a starch granule protein, SGP-1, of wheat generates an altered starch with apparent high amylose. Theoretical and Applied Genetics, 101: 21-29.

Yamazaki, W.T. (1953). An alkaline water retention capacity test for the evaluation of cookie baking potentialities of soft winter wheat flours. Cereal Chem.,30: 242-246

Yasui, T.; Ashida, K. and Sasaki, T. (2009). Chain- length Distribution Profiles of Amylopectin Isolated from Endosperm Starch of Waxy and Low- amylose Bread Wheat
(Triticumaestivum L.). Starch Stärke, 61: 677-686

Yoo, S.H. and Jay, L.J. (2002). Structural and physical characteristics of waxy and other wheat starches. Carbohydrate Polymers, 49: 297305.

Zhang, G.; Ao, Z. and Hamaker, B.R. (2008). Nutritional property of endosperm starches from maize mutants: A parabolic relation between slowly digestible starch and amylopectin fine structure. J. Agric. \& Food Chem., 56: 4686-4694.

Zhang, G. and Hamaker, B.R.(2009). Slowly digestible starch: Concept, mechanism, and proposed extended glycemic index. Critical Reviews in Food Science and Nutrition, 49: 852-867.

Zhang, H.; Zhang, W.; Xu, C. and Zhou, X. (2013).Morphological features and physicochemical properties of waxy wheat starch. Inter. J. Biolog. Macromolecules, 62: 304- 309.

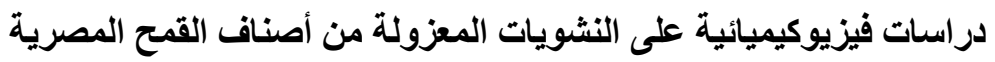

مروة محمود عبد العزيز محروس *1 ، ناصر شعبان علي محمد خليل1 ، محمد أحمد ميكوي2 ، عمرو عاطف السيد3

1 - المركز الإقليمي للأغذية و الأعلاف بالجيان الجيزة

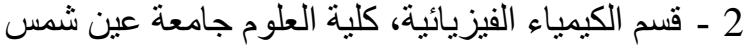

3 - قسم بحوث النسيج، المركز القومي للبحوث بالة بالدي

* marwamahmoud777@yahoo.com

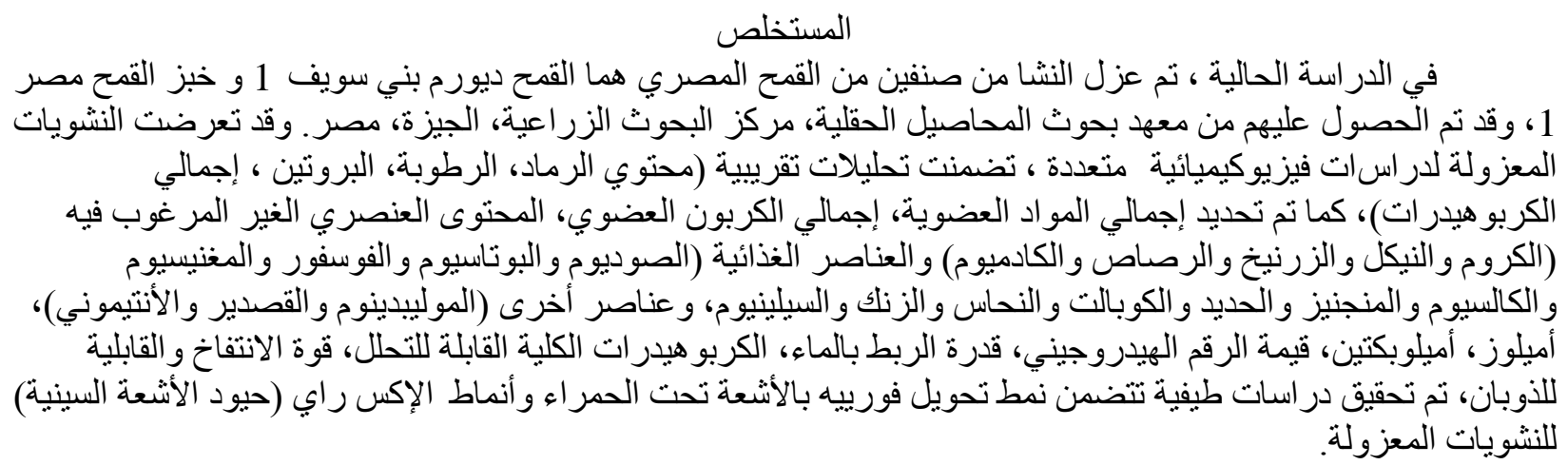

